Common Sense or Commonwealth? The Fence Law and Institutional Change in the Postbellum South

Author(s): Shawn Everett Kantor and J. Morgan Kousser

Source: The Journal of Southern History, Vol. 59, No. 2 (May, 1993), pp. 201-242

Published by: Southern Historical Association

Stable URL: http://www.jstor.org/stable/2209776

Accessed: 05-09-2017 23:01 UTC

JSTOR is a not-for-profit service that helps scholars, researchers, and students discover, use, and build upon a wide range of content in a trusted digital archive. We use information technology and tools to increase productivity and facilitate new forms of scholarship. For more information about JSTOR, please contact support@jstor.org.

Your use of the JSTOR archive indicates your acceptance of the Terms \& Conditions of Use, available at http://about.jstor.org/terms

Southern Historical Association is collaborating with JSTOR to digitize, preserve and extend access to The Journal of Southern History 


\title{
Common Sense or Commonwealth? The Fence Law and Institutional Change in the Postbellum South
}

\author{
By Shawn Everett Kantor and J. Morgan Kousser
}

\begin{abstract}
RaRely have SOUTHERN HISTORIANS DEVOTED AS MUCH ATTENTION TO A SIMPLE question of torts as they have in the instance of fence laws: would owners of livestock be held liable for damages to other people's crops if they did not fence in their animals (referred to as the "stock law"), or did crop owners have to fence out other people's cattle and swine (known as the "fence law")? In most of the sparsely settled pre-Civil War South, the open-range, or fence-law, position prevailed. Post-Civil War state legislation allowed voters in counties or subcounty districts to adopt laws that shifted rights to crop growers and town dwellers and away from owners of livestock, which effectively closed the range. ${ }^{1}$

Debates over this question, Steven Hahn contends in his sweeping reinterpretation of postbellum southern society and politics, reflected

${ }^{1}$ See, e.g., Georgia Acts . . . Adjourned Session, 1872, No.329, pp. 34-36. In 1881 militia districts were permitted to hold fence elections. See Georgia Acts . . 1880-81, No. 401, pp. 79-81. In the early postbellum period the Alabama and Mississippi state legislatures passed county-specific acts either allowing county or subcounty referenda or permitting landowners to petition county officials to enact the stock law. In South Carolina and in some counties and militia districts in Georgia, Alabama, and Mississippi, however, the stock law was imposed in the late nineteenth century by the state legislature without referenda or petition. See South Carolina Acts . . 1881-82, No. 472, pp. 591-94, and amended, No.603, p. 854. The Mississippi and Alabama legislatures authorized referenda in all counties and subcounty districts in 1892 and 1903, respectively. See Mississippi Acts . . 1892, Chap. 71, pp. 161-66; Alabama Acts . . 1903, No. 311, pp. 431-38. We wish to thank Lance Davis and Jean-Laurent Rosenthal for helpful discussions during our work on this paper and Doug Flamming and David Weiman for extraordinarily helpful comments on previous versions of this paper. Naturally, we retain strict property rights to any of the paper's remaining shortcomings.
\end{abstract}

Mr. KANTOR is an assistant professor of economics at the University of Arizona and faculty research fellow of the National Bureau of Economic Research.

MR. KOusSER is a professor of history and social science at the California Institute of Technology.

THE Journal of SOUTHERN HISTORY

Volume LIX, No. 2, May 1993 
struggles between an "agrarian bourgeoisie," on the one hand, and those who believed in "a cooperative principle that challenged the tenets of bourgeois individualism and property, that challenged the hegemony of the marketplace," on the other. ${ }^{2}$ This was not simply a clash between people or classes with different economic interests, Hahn believes, but a full-blown cultural/ideological struggle:

What underlay contention over the material consequences of the stock law were considerably different, and increasingly antagonistic, ideas about social relations and property rights. The freedom to which [stock-law opponents] adhered was not merely that founded upon ownership of one's person and exchange in the marketplace, but that founded upon control over productive resources, labor time, and subsistence which, in turn, could be realized only through membership in the commonwealth of producers. The stock-law controversy set the republicanism of those producers against the values of the free market. ${ }^{3}$

To its critics, according to Hahn, the stock law "was the starkest instance of efforts by the emerging postbellum elite to cast petty producers into a state of dependency." Central to Hahn's larger interpretation of the transformation of the nineteenth-century upcountry, the fence-law contests, in his words, "paved the road to Populism." 4 Actually devoting little direct attention to Populism itself, Hahn concentrates on two small counties in the Georgia hills, Carroll and Jackson.

In this article, we revisit the battles that Hahn addresses, evaluating his and others' hypotheses about fence-law conflicts within the two counties in his study. In addition to reexamining the published debate between proponents and opponents of this livestock-enclosure movement, we explicitly and rigorously test Hahn's and others' explanations by formulating competing models and assessing them with multivariate statistical methods. We find more subtlety and complexity in the debate and the clashes of interest than they appear to have in Hahn's presentation. While we do not doubt that differences over policy stances and ideology often move people to action, we do believe that the importance of such factors must be weighed against the evidence in each particular case, rather than automatically assumed to be determinative. ${ }^{5}$ In this instance, we show that it is possible to

\footnotetext{
${ }^{2}$ Hahn, The Roots of Southern Populism: Yeoman Farmers and the Transformation of the Georgia Upcountry, 1850-1890 (New York and Oxford, 1983), 239-53 (quotations on pp. 244 and 252).

3 Ibid., 250, 253-54. [Editor's note: see Steven Hahn, "Common Cents or Historical Sense?" p. 245, and Shawn Everett Kantor and J. Morgan Kousser, "Two Visions of History," p. 259, note 2, both in this issue, for discussions of this quotation.]

4 Ibid., 239, 240.

5 Douglass C. North, Structure and Chance in Economic History (New York and London, 1981) warns economic historians against arbitrarily assuming "rational" self-interest on the part of individuals. North shows that ideological beliefs must be equally considered as motivating factors in economic or political change. In other work, Kousser emphasizes the importance of ideology. See "The Supremacy of Equal Rights': The Struggle Against Racial Discrimination in Antebellum Massachusetts and the Foundations of the Four-
} 
choose between different explanations of motivation, and we argue that the conflict was over material, not cultural, matters.

Hahn is not the first to study southern fence laws-not even the first to focus on Carroll County. The late James C. Bonner viewed the debate mainly as a conflict between "small farmers in isolated areas and those living in more densely populated areas." The pre-Civil War southern economy had been almost wholly agricultural. After 1865 , periodic depressions, as well as the geographically uneven development of railroads, towns, and industries, created a "rural-urban schism" that was manifest in the local debate over the fence issue. The Populists' relative success in Carroll County in the 1890 s, according to Bonner, was the climactic result of the developing class conflicts in the local battles to close the open range. ${ }^{7}$ Proposing many of the core ideas later generalized to the entire South and expressed more vividly by Hahn, Bonner's 1971 monograph attracted much less response than Hahn's 1983 work.

Charles L. Flynn, Jr., also highlights the fence-law debate, which he refers to as "the bitterest political issue in Georgia politics between Redemption and the Populist Revolt of the 1890s." 8 But instead of a symbolic cultural battle, Flynn sees the contest as a purely material class conflict pitting relatively affluent landowning whites against the landless or landpoor, white as well as black. Although he admits the validity of some of the arguments of the stock-law proponents, Flynn judges partisans of that position "at least indifferent to the burdens that the change placed upon the poor." Spreading from the more populated, less forested black belt to the developing hill country, the dispute shifted from a contest predominantly between blacks and whites to one primarily between different classes of whites. "The fence-law controversy," Flynn contends, "illustrated the intersecting class and racial division in the life of the New South." While stock-law advocates wanted to minimize the expense of fencing and the property damage caused by marauding animals, fence-law advocates feared high charges by landlords and large farmers for the penned, watered grazing space that would be necessary if the fence law were repealed. ${ }^{10}$

In a geographically broader review of two centuries of southern grazing laws, J. Crawford King, Jr., details the gradual closing of the southern range. ${ }^{11}$ Rather than analyzing each side's stated rationale for acting, King

teenth Amendment," Northwestern University Law Review, LXXXII (Summer 1988), 941 1010.

'James C. Bonner, Georgia's Last Frontier: The Development of Carroll County (Athens, Ga., 1971), 143.

${ }^{7}$ Ibid., 139.

${ }^{8}$ Charles L. Flynn, Jr., White Land, Black Labor: Caste and Class in Late NineteenthCentury Georgia (Baton Rouge and London, 1983), 128.

${ }^{9}$ Ibid., 131.

${ }^{10}$ Ibid., Chap. 5 (quotation on p. 129).

${ }^{11}$ J. Crawford King, Jr., "The Closing of the Southern Range: An Exploratory Study," Journal of Southern History, XLIII (February 1982), 53-70. 
divides the counties of Alabama and Mississippi into those that had either partially or completely adopted the stock law by 1890 and those in which the open range persisted. Using 1880 census data, he then compares several of the objective traits of the two groups of counties: population density, racial proportions, farm-tenure arrangements and size, intensity of cultivation and concentration on cotton, and number of livestock (especially hogs) per person. Failing to employ any multivariate methods or explicit statistical models, King presents only a series of contrasts between the mean values of each variable in the two sets of counties. Although he concludes that his results "suggest a much more complex interpretation than the simplistic and somewhat artificial picture of battle between 'haves' and 'have-nots'," King does not flesh out such an interpretation himself. ${ }^{12}$

Historians are not the only scholars to notice fence laws. In a now classic 1960 paper, the economist Ronald H. Coase employs the example of a dispute between a farmer and a cattle raiser over who should compensate the other for the damage caused by livestock in the absence of a fence between their adjacent properties. ${ }^{13}$ In certain circumstances, Coase argues, the individuals would voluntarily come to an agreement that would maximize the value of what the two of them produced, regardless of who initially owned the grazing rights. A cooperative Coasian solution might not take place, however, if there were too many potential parties to the agreement. More bargainers would multiply the difficulty of gaining information about each individual's true preferences and behavior and therefore complicate the negotiation and enforcement of any contract. ${ }^{14}$ The same difficulties that would undermine a free-market solution would have a similar effect on a voluntary communitarian arrangement, unless every person in the community were altruistic, since non-altruists would have strong incentives to take advantage of their fellows' generosity. ${ }^{15}$

This probable contractual breakdown can be particularly disastrous in what natural resource economists refer to as "common pool" situations. ${ }^{16}$ If

${ }^{12}$ Ibid., 63-70 (quotation on p. 68).

${ }^{13}$ Ronald H. Coase, "The Problem of Social Cost," Journal of Law and Economics, III (October 1960), 1-44.

${ }^{14}$ Economists refer to such difficulties as "transaction costs," which include the costs of bargaining, information, supervision, enforcement, measurement, and political action. One of Coase's crucial assumptions, and, implicitly, one of Hahn's (see Roots of Southern Populism, 252-53, on "the abiding logic of the open range"), is that transaction costs are negligible. See Elizabeth Hoffman and Matthew L. Spitzer, "The Coase Theorem: Some Experimental Tests," Journal of Law and Economics, XXV (April 1982), 73 for an exhaustive list of Coase's assumptions. It is instructive that the arch-laissez-faire theorist and the radical historian share the zero-transaction-costs assumption.

${ }^{15}$ It is surprising that Coase and Hahn should emphasize the voluntary and/or communitarian aspects of the fence-law structure, for the traditional historical view is that requiring crops, rather than animals, to be fenced often fostered bitter, incessant conflicts. See, e.g., Earl W. Hayter, "Livestock-Fencing Conflicts in Rural America," Agricultural History, XXXVII (January 1963), 10-20.

${ }^{16} \mathrm{H}$. Scott Gordon, "The Economic Theory of a Common-Property Resource: The Fishery," Journal of Political Economy, LXII (April 1954), 124-42. 
fishermen do not consider the effect of their current actions on the welfare of others or themselves in the future, they may quickly deplete the resource. As long as the pond is overstocked, no human suffers. But if the supply of fish falls below a certain point, then every fish caught by one person is a meal denied to another. If the supply declines to a point below the replacement level, every fish taken hurts not only individuals other than the one fishing, but the society as a whole. Similarly, under the fence law, the owners of grazing animals could let them run free on other peoples' land. This law therefore encouraged stock raisers to increase the size of their herds beyond the size they would have maintained if they had to confine and feed the animals on their own property. Conversely, landowners in such a situation would tend to underinvest in improvements other than fences, lawyers' fees, and buckshot. ${ }^{17}$ Where there is plenty of forest or scrub land, free grazing may damage society less than the cost of enclosing the animals. But as the supply of forests, nuts, and grasses decreases, more and more farmers - renters and sharecroppers, as well as landowners-will suffer losses from roaming animals; and future generations will be robbed to allow for the rapid exploitation of resources in the present.

Since every farmer under an open-range regime has an economic incentive to transfer his own cost of raising livestock onto others, private contracts in this setting are difficult, if not impossible, to negotiate and enforce when there are many farmers. Such a situation inevitably creates a demand for government intervention; but because the strength of the competing groups varies, the government's ultimate decision is likely to be influenced by the power of each individual group. ${ }^{18}$ The final allocation of property rights dictated by the government, therefore, may not conform to the one that maximizes "social welfare" and offers no guarantee that the outcome would be equitable to any person or group.

According to Lance E. Davis and Douglass C. North, people will seek a change in the institutional status quo when the net present value of a new regime of property rights exceeds the net present value of the traditional set of rights. ${ }^{19}$ As the costs and benefits are continuously changing under each

\footnotetext{
${ }^{17}$ Stock-law advocates often charged that the status quo led to too many lawsuits. See, e.g., Carrollton (Ga.) Carroll County Times, January 10, 1873; Carrollton (Ga.) Carroll Free Press, May 8 and June 5, 1885; Jefferson (Ga.) Jackson Herald, April 15, 1881, August 24, 1883, and August 2, 1885.

${ }^{18}$ See for example George J. Stigler, "The Theory of Economic Regulation," Bell Journal of Economics and Management Science, II (Spring 1971), 3-21; Sam Peltzman, "Toward a More General Theory of Regulation," Journal of Law and Economics, XIX (August 1976), 211-48; and Gary S. Becker, "A Theory of Competition Among Pressure Groups for Political Influence," Quarterly Journal of Economics, XCVIII (August 1983), 371-400.

${ }^{19}$ Lance E. Davis and Douglass C. North, Institutional Change and American Economic Growth (Cambridge, Eng., 1971), 3-79. See also Harold Demsetz, "Toward a Theory of Property Rights," American Economic Review, LVII, No. 2: Papers and Proceedings of the Seventy-ninth Annual Meeting of the American Economic Association (May 1967), 347-59. For an overview of research in economic history on related questions of the political economy
} 
institutional structure, the net present value calculation will become a dynamic process that individuals and groups constantly update. Examples of changes that might have encouraged groups in upcountry Georgia to reassess the costs and benefits of keeping the fence law include technological advances in agriculture and animal husbandry, improved transportation, changes in population density, increases in cultivated acreage, and changes in the relative prices of certain commodities, such as timber, labor, animals, animal products, and agricultural produce.

While the inhabitants of the nineteenth-century Georgia upcountry were unaware of neoclassical economic theory, many of their arguments in the fence-law debate resemble those of modern economists. Like recent theorists of property rights and institutional change, nineteenth-century Georgians discussed prospective gains in farming efficiency and resource conservation. There was widespread agreement that the decision turned on the availability of timber for fences, the density of population, and the degrees of concentration on growing crops and raising stock. Since, unlike economists, the practical disputants were seeking to form majority coalitions in referenda, there was also considerable discussion of who might be expected to gain or lose if the institutional structure changed. By far the most common abstract or ideological appeal during the debate stressed the inconsistency of the fence law with private property rights - an indication that stock-law proponents believed that the citizens of the upcountry shared a belief in the moral correctness of private property rights. By contrast, invocations of traditional rights, which Hahn equates with "preindustrial republicanism," were a quite minor part of extant records of the debate over fence laws in Carroll and Jackson Counties; even those who referred to such rights treated them as exceptional and temporary constraints on a more general system of private property. ${ }^{20}$ Rather than an ideological conflict over abstract principles, the debate was largely a hard-headed clash of interests waged by pragmatic agriculturalists. "We know," said stock-law supporter S. B. Orr of Carroll County, "that people will vote for what they suppose to be personal interest in this matter."21

Georgia law from colonial times until after the Civil War essentially

of institutions, see Gary D. Libecap, "Property Rights in Economic History: Implications for Research," Explorations in Economic History, XXIII (July 1986), 227-52.

${ }^{20} \mathrm{Hahn}$, Roots of Southern Populism, 253. In an examination of much more recent conflicts over fence laws in Shasta County, California, Robert C. Ellickson emphasizes that most were settled by "norms of neighborliness," rather than by resorting to the law. In difficult cases, he notes, these informal methods included rhetorical backbiting and threatened or actual violence against intruding animals. Nevertheless, his interviews showed an almost universal belief that "an owner of livestock is responsible for the acts of his animals." In other words, they believed in what Hahn terms "absolute private property." See Ellickson, "Of Coase and Cattle: Dispute Resolution Among Neighbors in Shasta County," Stanford Law Review, XXXVIII (February 1986), 623-87 (quotations in footnote 20 are on p. 673).

${ }^{21}$ Carrollton Carroll Free Press, May 22, 1885. 
held that unfenced land could be used as common pasture. ${ }^{22}$ This was not an English or "Celtic" inheritance, for in the densely populated British Isles, common law did not force property owners to fence in their crops. ${ }^{23}$ Rather, owners of animals were required to keep their stock on their own property, and stray animals on a neighbor's enclosed or unenclosed land were considered trespassers. Vast unimproved land and sparse settlements in America, however, made it economical to allow animals to roam the countryside freely. Eventually, landowners were compelled either to erect and maintain "lawful" fences or to forgo legal claims to compensation for damages caused by another person's animals. ${ }^{24}$ Georgia's first fence law, passed in 1759 , explicitly required that:

All fences or enclosures that shall be made around or about any garden, orchard, rice ground, indigo field, plantation or settlement in this province, shall be six feet high from the ground when staked or ridered and from the ground to the height of three feet of every such fence or enclosure, the rails thereof shall not be more than four inches distant from each other; and that all fences or enclosures that shall consist of paling shall likewise be six feet from the ground and the pales thereof not more than two inches asunder: Provided always, that where any fence or enclosure shall be made with a ditch or trench, the same shall be four feet wide, and in that case the fence shall be six feet high from the bottom of the ditch. ${ }^{25}$

Those whose fences did not adhere precisely to the fence law were subject to treble damages if they killed or injured a stray animal on inadequately fenced land. ${ }^{26}$ In the 1881 decision of Hamilton v. Howard, the Georgia Supreme Court declared that a lawful fence had to rise five feet from the

${ }^{22}$ Even under the fence-law regime, "common rights" were not unlimited. Although people were free to allow their animals to roam the countryside, they did not, according to the Georgia Supreme Court, have a lawful "common title" to unenclosed land. In Wright H. Harrell v. Hannum and Coleman ( $56 \mathrm{Ga} .508$ [1876]), the court ruled that a cattle farmer did not have a right to pasture in the woods or upon the unenclosed land of others. The cattle farmer, said the court, "does not set forth any contract, prescription or other lawful basis for the right he claims. What belongs to the world at large is no man's in particular...."

${ }^{23}$ For the alleged contrast between English and "Celtic" fencing practices, see Grady McWhiney and Forrest McDonald, "Celtic Origins of Southern Herding Practices," Journal of Southern History, LI (May 1985), 165-82. For a masterful critique, see Rowland Berthoff, "Celtic Mist Over the South," ibid., LII (November 1986), 523-46.

${ }^{24}$ Washburn and Moen Manufacturing Co., The Fence Question in the Southern States as Related to General Husbandry and Sheep Raising, with the History of Fence Customs, and Laws Pertaining Thereto: And a View of the New Farm System of the South, as Shown in the Census of 1880 (Worcester, Mass., 1881), 10-11. For a discussion of the development of the openrange system in New England, see William Cronon, Changes in the Land: Indians, Colonists, and the Ecology of New England (New York, 1983), Chap. 7.

${ }^{25} \mathrm{Hahn}$, Roots of Southern Populism, 60-61. In the early nineteenth century, however, the Georgia General Assembly did reduce the legal height of fences by a foot. Ibid.

${ }^{26}$ It is unclear how widespread "lawful" fences were, for census figures do not distinguish between lawful and short or rickety fences. One Georgia observer declared that "a lawful fence is of rare occurrence in the older counties." See C. W. Howard in Carrollton Carroll County Times, January 10, 1873. 
ground everywhere, rather than merely averaging that height. ${ }^{27}$ Furthermore, an 1889 decision ruled that an agreement to dispense with a partition fence (one between two neighbors) was not the equivalent of a legal fence. Unless an actual fence-not merely a contract or agreement to dispense with a fence or an agreement to treat a dividing line as a fence-were broken, it was illegal for a farmer to harm a stray. ${ }^{28}$ The court's message throughout was clear: a legal fence was defined absolutely with no room for variations.

In the post-Civil War era, as population expanded throughout the South, as blacks took advantage of their freedom to move, and as the growth of the railroad network facilitated marketing crops from previously isolated areas, population density increased in the Georgia upcountry. Carroll County's population growth was especially rapid: the black population surged 77 percent during the 1870 s and 67 percent during the 1880s; the white population also increased relatively quickly, with a total gain of 76 percent over the two decades. Jackson County's black population multiplied at a more modest rate, with an 1870 to 1890 total of 45 percent, but the white sector shot up 84 percent over the two decades. Overall, Carroll County's population grew by 89 percent from 1870 to 1890 ; and Jackson's, by 72 percent. $^{29}$

To stock-law supporters, the increasing pressure on the land required that it be used more efficiently. ${ }^{30}$ Almost all nineteenth-century southern farmers used "worm" fences to enclose their crops and fences made of pales for their gardens and homesteads. Because worm fences were constructed by laying the ends of rails on top of each other, zigzag fashion, a three-and-a-half to four-foot strip of land on each side of the fence was wasted. ${ }^{31}$ For every mile of fence, approximately one acre of productive land was squandered. Writing from the adjacent county of Coweta, which had already adopted the stock law, J. P. Reese (alias "Ripples") contended that "the old fence rows of Carroll county will make corn enough in three years to pay for all the crops that will grow in the county for the next ten years." 32 Other savings could be made because improving small patches of fertile land would be profitable if they did not have to be protected by

${ }^{27}$ Hamilton v. Howard, 68 Ga. 288 (1881).

${ }^{28}$ Tumlin v. Parrott, 82 Ga. 732 (1889).

${ }^{29}$ A possible undercount of the Carroll County black population in 1870 does not detract from these trends. If 1860 , rather than 1870 , is used as the base year, the growth rates of the total population in the two counties were 86 percent and 81 percent, respectively.

${ }^{30}$ There was only a small movement to enact stock laws in the comparatively sparsely settled antebellum South. See King, "Closing of the Southern Range," 55-56.

${ }^{31}$ Carrollton Carroll Free Press, May 22, 1885; and Washburn and Moen, Fence Question, 16. "Subscriber," in Southern Cultivator, XXXVI (January 1878), 7, gave the total width of the strip as between six and seven, rather than eight, feet.

32 Carrollton Carroll Free Press, April 17, 1885. In the heat of argument, "Ripples" unquestionably exaggerated. 
fences. ${ }^{33}$ Jackson County's Eugene F. Adair predicted that "if there was a law compelling owners of stock to keep them under a fence, we could clear and plant just such pieces of land as we thought best. Leaving out the poorest, we could plant where we pleased, no matter how small, or in what shape it might be." 34 Defenders of the fence law derided the claimed savings in land as exaggerated, but they denied neither the general point nor its importance. ${ }^{35}$

The consensus among both stock-law and fence-law supporters that the choice between the two laws depended on the demographic, ecological, and economic conditions of the locale demonstrates that this was not primarily a cultural controversy. As T. D. Henderson, the state agriculture commissioner, noted, "It is not expected that the stock law will be adopted in the wire-grass counties of the state, where the larger area is in pasture." In most of the counties of north Georgia, however, "the adoption of the stock law is only a question of time," he believed. ${ }^{36}$ Likewise, at the 1878 meeting of the Georgia State Agricultural Society, a stock-law opponent from Clay County conceded, "In Middle and Upper Georgia, I have no doubt it [the stock law] would operate well; but it would not do in Southern Georgia. No further south than Decatur county there are thousands of acres good for stock, and unless the stock run at large these lands do no good." ${ }^{37}$ In an 1883 editorial, the Jefferson (Ga.) Jackson Herald declared, "It stands to reason, that in an agricultural country stock is not of such great importance as the

\footnotetext{
${ }^{33}$ Since the area of a square piece of land increases by the square of each side, and that of other shapes grows by similar amounts, owners of small plots had to split proportionately many more rails than owners of larger farms, if, indeed, either fenced in his land. A simple example shows the consequences in wasted land. Suppose a piece of land were square and 100 feet on each side. Then the total area would be $100 \times 100=10,000$ square feet. The amount occupied by a worm fence would be $100 \times 7 \times 4=2,800$ square feet (i.e., length times width times number of sides). (We used the smaller estimate of width to minimize the figure for wasted land.) But at each corner, the fences would overlap, so we must eliminate $7 \times 7 \times 4=196$ square feet (width times width times number of corners). So the fence would take up 2,604 square feet, or 26 percent, of the land. If the square were 1,000 feet long, a similar calculation shows that the percentage occupied by the fence would amount to only about 2.8 percent of the larger field. (If all fences were on the edges of every farmer's land, so that only half of the width of each fence would have to be subtracted from the land of each farmer, the calculations would lead to analogous percentages of 13.5 and 1.4.) This admittedly extreme example demonstrates two principles: first, it could be relatively wasteful to fence small fertile portions of fields; second, where fences were maintained, the burden of the fence law fell disproportionally on small, not large, farmers.

${ }^{34}$ Jefferson (Ga.) Forest News, December 24, 1880. The Jackson Herald was the successor to this newspaper.

35 "Subscriber," in Southern Cultivator, XXXVI (January 1878), 7-8.

${ }^{36}$ Henderson quoted in Carrollton Carroll County Times, August 4, 1882. For a detailed calculation of the discounted net present value of the expected profitability of a change to the stock law in the six standard regions of Georgia in 1880, which strongly supports Henderson's statement, see Shawn Everett Kantor, "Razorbacks, Ticky Cows, and the Closing of the Georgia Open Range: The Dynamics of Institutional Change Uncovered," Journal of Economic History, LI (December 1991), 866-70.
}

${ }^{37}$ Proceedings of the Georgia State Agricultural Society, 1876 to 1878 (Atlanta, 1878), 415-16. 
crops, hence they should be confined. If this was a stock country the crops, which would be small and insignificant, ought to be fenced." 38 Although he disagreed with the newspaper about which arrangement was to be preferred, a fence-law advocate from the Fair Play district of Jackson County accepted the notion that the decision on whether to adopt the stock law depended on "denseness or sparseness of population, the geographical situation, irrigation ...." 39

On this issue, each side's proponents in Carroll and Jackson Counties clashed less on principles than on facts. Thus, "School Boy" of Carroll County admitted that "when our fathers first settled this connty [sic] and our range was good and when the acreage in cultivation was [s]mall, the present system of fencing was proper, but now we have no range, cows are hungry and often in our or our neighbors fields, the acreage of cleared land is more than that for pastures." porter, asserted that "There is at least three-fourths of our land in the range or commons . . .." Longtime Carroll County resident and stock-law supporter J. O. R. Word reflected on earlier days: "Forty nine years ag[o] father moved to [t]his county. It was then a fine range for stock. I $[t]$ was then the best economy to fence up our crops, for our farms were small and far between and range fresh and large." 42 In Jackson County in 1876 John G. Justice, a prominent Democrat whose farm was worth three-and-a-half times the value of the average farm in Jackson County, contended that the county was not yet suitable for the stock law, which was "only adapted to those countries so densely populated as to afford no pasturage outside the enclosed lands ...."43 Ten years later, "J. B." of the same county came to quite a different conclusion: "There is absolutely nothing outside [the fenced areas] for the stock to graze on-no range worth anything ...."44 "Ripples" stated it more succinctly: "This is not a range country like it once was." 45

Though more rhetorical, other statements by fence-law champions also accepted the common pool argument. White Republican and stock raiser William D. Lovvorn of Carroll County saw no reason for the stock law because "the woods are full of grass and acorns part of the year. They were

${ }^{38}$ Jefferson Jackson Herald, July 20, 1883.

${ }^{39}$ Ibid., June 17, 1881.

${ }^{40}$ Carrollton Carroll County Times, September 1, 1882.

${ }^{41}$ Ibid., September 8, 1882.

42 Carrollton Carroll Free Press, May 1, 1885.

43 Jefferson Forest News, September 16, 1876.

${ }^{44}$ Jefferson Jackson Herald, March 5, 1886.

${ }^{45}$ Newnan (Ga.) Herald, June 30,1881 . For other examples of agreement by both sides on the criteria of "denseness or sparseness of population, the geographical situation, irrigation," and other factors, see, e.g., Jefferson Forest News, September 19, 1879; Jefferson Jackson Herald, June 17, 1881; and Carrollton Carroll Free Press, April 17 and May 1,1885 . Both Carroll and Jackson Counties were below the state average in the number of milch cows, other cattle, sheep, and swine, and the overall value of livestock in 1880 , and above the state average in the proportion of improved acreage to total farm acreage. 
put here by our Creator for benefit to his people, and I don't think it right to deprive a large majority to please a minority." ${ }^{46} \mathrm{~J}$. W. Pitts expanded Lovvorn's analysis: "We have acorns, hickory-nuts, chestnuts and $\mathrm{m}$ [o]ss for hogs and in most parts we have a splendid range of grass. Wouldn't it be foolishness to shut our stock from it? Of course it would." Although Pitts believed that Carroll's natural resources were large enough to make the stock law unnecessary, he did not categorically dismiss the idea that fences would one day be necessary: "While they [trees] are all cut down and washed away in a great many places, Carroll boasts of plenty of timber, one thousand acres or more in one body, while the fields are small. It's the other way in those counties [that have adopted the stock law], and when Carroll gets in that condition we'll give up for no fence, and not before." 47

Reformers in Jackson and Carroll Counties claimed that the stock law would save farmers both labor and capital. "It takes away most of the profit of farming to keep up good fences," announced I. H. P. Beck, a landless farmer, schoolteacher, and later local leader in the Farmers' Alliance and the Populist and Republican parties. ${ }^{48}$ "P." of Thompson's Mills, Jackson County, estimated that "it takes one-tenth of the time spent on the farm to repair fences. Could not we spend it more profitably? Could we not use that time in making compost heaps?"49 "Plow Boy" suggested that "we should dispense with fences ... because we could spend our time at something that would be much more remunerative than patching up fences such as making our manure heaps larger, stopping washes, etc., besides we would have no other stock to see after but our own." ${ }^{\circ 0}$ Likewise, Eugene Adair asserted that "while we used to split and haul rails, we could, under this artangement [the stock law], with the same labor, be making manure to improve the land intended to be cultivated." 51 Farmers cared more about compost heaps than capitalism.

\footnotetext{
${ }^{46}$ Carrollton Carroll Free Press, June 5, 1885. For Lovvorn's longtime Republican activism, see ibid., March 15, 1895. According to the 1880 census manuscripts, the value of Lovvorn's livestock was higher than that of any other participant in the fence-law debate in the two counties who could be traced to the census. Philo H. Chandler, who switched sides during the 1880 s and became a stock-law supporter, valued his livestock at the same amount as Lovvorn did. Lovvorn owned seventy-five acres of forest land and fifty-nine tilled acres, and his livestock was worth nearly four times that of the average owneroperated Carroll County farm.

${ }^{47}$ Carrollton Carroll County Times, August 25 and September 8, 1882.

${ }^{48}$ Carrollton Carroll Free Press, May 15, 1885. For Beck's Alliance, Populist, and Republican activity, see ibid., February 28, 1890, April 15, May 6 and July 8, 1892, and March 15, 1895.

${ }^{49}$ Jefferson Jackson Herald, August 3, 1883.

${ }^{30}$ Carrollton Carroll Free Press, April 17, 1885.

${ }^{31}$ Jefferson Forest News, December 24, 1880. Similarly, see Proceedings of the Georgia State Agricultural Society, 1876 to 1878, pp. 412, and 419-22; Home and Farm, quoted in Jefferson Forest News, April 23, 1880; Anson (N.C.) Times, quoted in Jefferson Jackson Herald, April 15, 1881; Carrollton Carroll Free Press, May 22, 1885; Southern Cultivator, XXXV (August 1877), 299-300; and Southern Cultivator and Dixie Farmer, XL (December 1882), 17, and XLI (June 1883), 2.
} 
Other stock-law advocates tried to make more precise calculations of the economic disadvantages of the status quo. "The whole subject," the Jefferson Jackson Herald announced, "is one that can be reduced to dollars and cents." 52 For instance, "School Boy" claimed that "the fences of Carroll county are worth three times more than all the hogs, cows and sheep in the county, and I . . ask ... if it is economy for a man to have one dollar invested in a business and it takes three $t[0]$ keep that one dollar up." $53 \mathrm{~A}$ correspondent from Villa Rica in Carroll County contended that "the land taken up by the fence around a man's farm will produce more than the value of the stock fenced out." 54 After diligent computation, "Vande Linctum" found that "for every dollar invested in livestock in the State, two dollars are required for the construction of fences to protect the growing crops."55 "Hopeful" from Human's Store, Jackson County, "found out that it costs us twice as much to fence out stock as it does to pay our taxes, and besides we have had about enough of our crops destroyed by stock to pay our taxes ...." ${ }^{56}$ Adair of Jackson County computed an initial cost of $\$ 210$ for the materials and labor needed to fence one hundred acres. ${ }^{57}$ One of the few stock-law opponents to counter this argument, Abner Nixon, who tilled nearly twice as many acres as the average owner-operator in Carroll County and whose farm was worth nearly twice the county average, admitted that fencing stock would save timber but preferred, instead, more intensive farming: "I think a better way would be for us to turn out more than half our land we have under old broke down fences and put good fences around as much land as we can put in a proper state [of] cultivation. It would certainly be much better to raise 40 bushels of corn per acre on 8 acres of [land] than 8 bushels per acre on 40 acres of land." ${ }^{88}$ Both stocklaw advocates and opponents showed the calculating state of mind

${ }^{52}$ Jefferson Jackson Herald, June 20, 1883.

${ }_{53}$ Carrollton Carroll County Times, September 1, 1882.

${ }^{34}$ Carrollton Carroll Free Press, May 1, 1885.

${ }^{35}$ Jefferson Jackson Herald, June 17, 1881.

${ }^{56}$ Jefferson Forest News, September 5, 1879.

${ }^{57}$ Ibid., December 24, 1880. Similarly, see Southern Cultivator, XXXIV (May 1876), 17879, (June 1876), 220, XXXV (August 1877), 299-300, and XXXIX (January 1881), 15-16; Carrollton Carroll County Times, August 4, 1882; and Newnan Herald, July 28, 1881.

${ }^{58}$ Carrollton Carroll Free Press, June 26, 1885. For a similar argument from a legal (not a moral) angle, see "Noxin Renba" (Abner Nixon spelled backwards) ibid., May 8, 1885. In the June 26 letter, Nixon also responded to the contention that the depredations of wandering stock unfairly reduced the value of farmers' land by arguing that the price of land had always taken into account the fact that stock could run free: "The citizens of this county have and always have had the legal, moral, and the Bible right to let their stock, unless of a dangerous character, run at large. We all know [sic] this when we purchased our lands." Since he embedded his reference to "Bible right" in a rather sophisticated classical economic argument, the religious phrase should not be interpreted, as $\mathrm{Hahn}$, in Roots of Southern Populism, 252, does, as evidence of adherence to "a vision of the cooperative commonwealth." Both sides, of course, could and did claim biblical authority. Stock-law supporters in a debate at Lickskillit, Georgia, contended that "the law is a legal law and can be established by the scriptures as just and right." Carrollton Carroll Free Press, June 5, 1885. If "B.'s" stock destroyed "A.'s" crops, remarked a Sparta, Georgia, farmer, 
characteristic of capitalism, and neither side rejected the market.

Even more often than they stressed saving labor and capital, reformers prophesied that the stock law would improve the quality of livestock and, thus, yield better meat and dairy products. ${ }^{59}$ While fencing in stock might reduce the quantity of livestock, the improved quality of the animals would more than compensate for the loss in number. The argument by "Ripples" was typical:

The milk and butter is free from poisons taken from cows that are kept up [i.e., fenced in] and then you know what your cattle eat. But when they woods it, you don't know when you are drinking or eating deadly poisons. Butter made from cows kept up is much richer than from those cows that are allowed to run at large. There is as much difference as between gold and nickle silver. The beef is fatter, tenderer and better. Breed stock can be improved. One good cow well fed and pastured is worth 5 ticky woods cows. Two hogs kept up is worth ten razor backs running at large.

Others asserted that Coweta County, which passed the stock law in 1881, was self-sufficient in meat while Carroll was not. "Here are two counties, one self sustaining and the other not," "Plow Boy" wrote in 1885 in the Carrollton (Ga.) Carroll Free Press, "and yet some will tell you that you cant raise hogs in a stock law county." "Ripples," who lived in Coweta but often wrote for the Carroll County newspapers, admitted that "we don't have quite so many hogs over here in Coweta as we used to have" before Coweta passed a stock law, but he assured residents of Carroll County that Coweta hogs "are a heap bigger and fatter." ${ }^{60}$ The response by "L. F. L.," that "Grandpa and grandma milked ticky cows and they lived a heap better than we do," was almost self-mocking. ${ }^{61}$

Unlike their grandparents, upcountry residents of the late nineteenth century increasingly enjoyed easy access to national and international markets. What James C. Bonner concluded about Carroll County characterized the whole upcountry: "The railroads did more to quicken the economic tempo of Carroll County than any other event during [the nineteenth] century." ${ }^{2}$ Railroads reached Carrollton, Carroll County's seat,

\footnotetext{
"it is clear that as B.'s property caused the damage, he ought to be the loser. The Bible sustains this idea, as in the case of A.'s ox killing B.'s ox." Southern Cultivator XXXVI (December 1878), 451. Private property, according to a North Carolina paper quoted ibid., XXXIX (January 1881), 15-16, "is founded upon correct moral principles, laid down in the first legal work ever given to man, the code, by that great law giver, Moses."

${ }^{39}$ For evidence of the correctness of their prophecies, see Kantor, "The Causes and Consequences of Southern Enclosure, 1850-1890" (unpub. paper, University of Arizona, 1991).

${ }^{60}$ Carrollton Carroll Free Press, April 17 (first and second quotations), May 1 (third quotation), 1885. Similarly, see Carrollton Carroll County Times, January 10, 1873, and September 8, 1882; Anson Times, quoted in Jefferson Jackson Herald, April 15, 1881; Jefferson Jackson Herald, August 24, 1883, October 31, 1884, March 20 and August 2, 1885; and Carrollton Carroll Free Press, June 19, 1885.

${ }^{61}$ Carrollton Carroll Free Press, April 24, 1883.

62 Bonner, Georgia's Last Frontier, 99. Georgia railroad miles increased from 1,548 in
} 
in 1874; Villa Rica, the county's second largest town, in 1882; and Jefferson, the Jackson County seat, in 1884. Not only did the railroad allow farmers and stock raisers to market their products more cheaply and efficiently, it also helped to increase production itself by enabling upcountry farmers to import large amounts of commercial fertilizer. ${ }^{63}$ Increased productivity and profitability in turn stimulated the land market, which raised the stakes of the fence-law controversy.

Like railroad promoters, fence-law reformers focused on future economic gains. In a Darwinian allusion, "Edgar" declared that "we must learn to give way to the fittest, for by so doing we will keep prospering, and if not, we will never prosper." 64 Even more certain of the stock law's necessity, Jackson County's "P." stated, "I regard it [the stock law] as the preliminary step to the prosperity of the agriculturalists of Jackson county."65 On the eve of the first fence election in Carroll County, "Ripples" chided his opponents: "Dont say the time is not yet come to begin to economize."66 Opponents were guilty of "old fogyism, general ignorance and backwardness" for favoring a system in force "in no civilized portion of the world."67 "Economy is what the Southern farmer has not learned yet." ${ }^{18}$ Stock-law champions would teach him.

While advocates of the new regime stressed progress, their opponents just as superficially invoked tradition. Thus, Jackson County's "Fair Play" forthrightly sought to preserve the status quo: "Our present system of fencing is an old one-so old that it would seem cruel to attempt an innovation upon it." Another saw the fence law as an embodiment of "the liberty that our forefathers fought for." "Go "G. W. C." of Carroll County expressed a different attitude toward risk than his stock-law neighbors: "He [I. H. P. Beck] says that he would rather jump into something new than to stand still and die in stagnation. There's where we differ, I would rather stagnate than to die in the stock law." Such statements made easy targets for New South rhetoric: "'By long usage our people are accustomed to the wagons, and why should we now try to supplant them by an engine?

1867 to 2,459 in 1880 (a 59 percent increase) and to 4,600.8 in 1890 (a further 87 percent increase). See H. V. and H. W. Poor, Poor's Manual of Railroads of the United States (New York, 1868-1924), 1880 Vol., p. v, 1888 Vol., p. xxv, and 1895 Vol., p. xxxvi. The best brief introduction to the development of the postbellum upcountry economy in Georgia also emphasizes the importance of the railroad. See David F. Weiman, "The Economic Emancipation of the Non-Slaveholding Class: Upcountry Farmers in the Georgia Cotton Economy," Journal of Economic History XLV (March 1985), 71-93.

${ }^{63}$ See Hahn, Roots of Southern Populism, 145-52; and Weiman, "Economic Emancipation."

${ }^{64}$ Carrollton Carroll County Times, September 1, 1882.

${ }^{65}$ Jefferson Jackson Herald, August 3, 1883.

${ }_{66}$ Carrollton Carroll County Times, September 8, 1882.

${ }^{67}$ Home and Farm, quoted in Jefferson Forest News, April 23, 1880.

${ }^{68}$ Carrollton Carroll County Times, May 3, 1878.

${ }^{69}$ Jefferson Jackson Herald, June 17, 1881.

${ }^{70}$ Quoted in Flynn, White Land, Black Labor, 131. 
Whew! Supreme folly!' The fence law as we now have it was itself, at one age of the world, a new thing." Or, as another reformer jeered: "Does improvement, progress and enterprise mean cruelty? Then Webster stands revised."71

What the stock-law advocates wished to conserve was not the rhetorical ideals opportunistically employed by both sides in the controversy, but tangible resources. They thought that unchecked exploitation of forests to build extensive networks of fences robbed future generations and threatened to denude the areas of timber. As J. O. R. Word insisted, "this is a question of vast importance not only to the present, but to the future generation," and a few weeks later he declared, "I speak in behalf of saving the timber for the benefit of the future generation ...." "Vande Linctum" claimed that "the repair of fences annually calls for the destruction of nearly 100,000 acres of timber, which, when taken in connection with other depletions of forest in the next half century, will leave the entire country destitute of timber." Moreover, since railroads not only used wood for ties but also made it possible to sell timber in a larger marketplace, the expansion of the rail network made lumber more valuable than it had been when the upcountry was isolated and self-sufficient. As "Ripples" remarked, "If I owned the timber of Carroll county I would not want any bigger fortune. The way to save your timber is adopt the stock law." 2 Although the Georgia General Assembly of 1879 allowed barbed wire to be classed as a legal fence for the purpose of keeping out larger draft animals, the wire was relatively expensive, and reformers believed, no doubt correctly, that upcountry farmers would continue to build more wooden fences for some time. ${ }^{73}$

To concrete arguments for efficiency, prosperity, and conservation, stock-law advocates sometimes added more philosophical appeals. The concept of private property, proponents of the stock law repeated endlessly, was incompatible with the open range. Apparently realizing the potency of an appeal to private property, opponents of the stock law rarely responded, as they presumably would have if they had believed that there was a consensus on communitarian values. "What belongs to me I have a perfect right to do as I please with it, what does not, I have no right to at all,"

${ }^{71}$ Carrollton Carroll Free Press, June 19, 1885 (first quotation); and Jefferson Jackson Herald, June 24, 1881 (second and third quotations).

72 Carrollton Carroll Free Press, May 1 and June 12, 1885 (J. O. R. Word quotations); Jefferson Jackson Herald, June 17, 1881 (Vande Linctum quotation); and Carrollton Carroll County Times, September 8, 1882 (Ripples quotation). In the Middle West, the conflict over fence laws began in the 1840 s and 1850 s because of the area's smaller timber resources, according to Hayter, "Livestock-Fencing Conflicts," 13.

${ }^{73} \mathrm{Ga}$. Acts . . 1878-79, No. 304, p. 165. The specifications of the legal barbed wire fences were revised in $G a$. Acts . . 1882-83, No. 440, p. 139. It was not only the relative cost of barbed wire that bothered farmers but also that the wire was thought to injure animals who ran against it. For evidence that farmers were cautious about adopting wire fences, see Southern Cultivator, XXXIX (October 1881), 376 and (December 1881), 444. 
remarked S. B. Orr of Carroll County. ${ }^{74}$ "I am compelled to build a lawful fence: or in other words a fence, 'horse-high, bull-strong and pig-tight,' to protect my own growing crop," said "P." of Thompson's Mills, Jackson County. "Is that just? If this land belongs to me, has your stock any right to anything that grows upon it without my consent? That is my property. As a matter of justice, as a matter of policy, what right have you to the grasses that grow on the land of your neighbor? It is only a permissive right, there is no legal or moral right in it."75 "Where does one man have a right to let his stock run over, and feed upon another's land?" asked "L.," a landless citizen of Carroll County in $1878 .^{76}$ Future Populist district committeeman I. H. P. Beck proclaimed, "A man's land is his own and one man's cow has no right to run on another's land inclosed [sic] or not." $" 77$

Drawing on familiar Jeffersonian rhetoric, reformers attacked fence laws as incompatible with republican independence. As " $\mathrm{L}$." advised, "If you have stock, own a piece of land to put them on, and keep them; not have them, and allow them to run over other's property. ${ }^{78}$ Not only did stocklaw advocates claim that roving stock illegally violated their personal property rights, they also believed that their neighbors had a moral obligation to respect these rights. Appealing to the individualistic tradition of natural rights, J. O. R. Word proclaimed that "from a sense of justice between man and man, I think that every man should be compelled to take care of his own stock, that he has no moral right to turn loose his stock to prowl around upon his neighbor's crop." ${ }^{29}$ Illustrating the incongruity of common grazing rights within a more general system of private property, proponents of the stock law posed homespun analogies: "A man has as much right to take his household and kitchen furniture and put it in another man's house and kitchen, as he does for his stock to run on his neighbor's enclosed or unenclosed [land]." ${ }^{80}$ A Carrollton Carroll Free Press reporter from Villa Rica described the logical implication of a law that allowed an individual's stock to graze upon a neighbor's land: "If he has this right, then by the same reasoning, he would be entitled to all the property not sheltered. A buggy or wagon left from under the shelter would be public property." 81

${ }^{74}$ Carrollton Carroll Free Press, May 1, 1885.

${ }_{73}$ Jefferson Jackson Herald, August 3, 1883.

${ }^{76}$ Carrollton Carroll County Times, June 7, 1878.

77 Carrollton Carroll Free Press, May 15, 1885. Similarly, see Southern Cultivator, XXXIV (June 1876), 220, (December 1876), 461, XXXVI (December 1878), 451, XXXIX (January 1881), 15-16, XL (December 1882), 17; Proceedings of the Georgia State Agricultural Society, 1876 to 1878, pp. 412, 415, and 419-22; Home and Farm, quoted in Jefferson Forest News, April 23, 1880; Jefferson Jackson Herald, June 17, 1881, June 29, 1883, and April 3, 1885; and Carrollton Carroll County Times, January 10, 1873, and September 1, 1882.

${ }^{78}$ Carrollton Carroll County Times, May 3, 1878.

${ }^{79}$ Carrollton Carroll Free Press, May 1, 1885.

${ }^{80}$ Ibid., April 17, 1885.

${ }^{81}$ Ibid., May 1, 1885. The editor of the Athens, Georgia, Southern Cultivator, XXXVI (January 1878), 8-9, stated the rights claim and the contradiction succinctly: "If one holds 
Significantly, opponents and proponents of the stock law agreed on the desirability of protecting private property, but they disagreed on the best way to do so. Private property seemed commonsensical to men of the nineteenth-century upcountry. Thus, fence-law supporter "Fair Play" of Jackson County declared that "viewing the question from a strictly legal standpoint, it would seem to be just to enact some law whereby every one should be protected in the full use and enjoyment of whatever property rightfully belonged to him; as for instance it would appear meet and proper that the owner of lands should have the same right to restrain others from grazing stock on his premises as he would to prevent them from felling his timber." ${ }^{82}$ Although Hahn leaves out the part of the letter by "Fair Play" just quoted, he does quote the succeeding lines: "Our present system is an old one-so old that it would seem cruel to attempt an innovation upon it. From long usage our people have become accustomed to it, and any change in or abridgment of it will unquestionably work serious injury to a large number of our citizens." Far from reflecting a competing moral system or "expression of natural right," as Hahn contends, the whole statement by "Fair Play" accepts private property as moral but bemoans its consequence for those who would be losers if the open range were closed. This is hardly tantamount to endorsing a "cooperative commonwealth" but rather represents a standard political appeal that has been used by the Right as well as the Left from time out of mind. ${ }^{83}$

Agreement on the principle of private property left fence-law advocates open to charges of inconsistency: "Why is it," asked "Vande Linctum" of Jackson County, "that if I climb over my neighbor's fence, four and a half feet high, and cut, trample, break down, or in any manner injure or destroy his wheat, com, cotton or other crops, that the law punishes me, yet my stock may cross the very same fence and commit the same depredations and the law protects them?"84 While Hahn admits that fence-law supporters believed in some private property rights, he contends that only stock-law advocates accepted what he terms "absolute property" and that private property and free-grazing rights did not appear contradictory in nineteenthcentury upcountry society. But as the statement by "Fair Play" demonstrates, the fine distinction is Hahn's, not that of the debaters of the 1880 s, and the contradiction was as evident to at least some nineteenth-century eyes as to those of the twentieth century. ${ }^{85}$ Although other fence-law supporters

a fee simple to land, he is entitled to all the fruits and benefits of it, including pasturage. His neighbors have no right to pasture their stock upon it. . . . If all your neighbors should fence in all their lands, your stock would be confined to your own land for support; but you could not complain, for it is fully admitted they have the right to enclose every acre they own."

${ }^{82}$ Jefferson Jackson Herald, June 17, 1881.

${ }^{83}$ Hahn, Roots of Southern Populism, 252.

${ }^{84}$ Jefferson Jackson Herald, June 10, 1881. A legal fence was five feet tall.

${ }^{85}$ Hahn, Roots of Southern Populism, 251 (quotation), and 253. 
ignored the contradiction between the principle of private property and the practice of unimpeded grazing, their silence provides no evidence that they explicitly questioned that principle, which Hahn's larger argument requires. Rather, free grazing was for them merely a convenient exception to the regime of private property.

Since the decision on whether or not to enforce strict property rights would be made by voters in collective referenda rather than by individual bargainers in a market, a good deal of the debate consisted of appeals for support and attempts to shape coalitions. Although they did not use the phrase, stock-law proponents understood the concept of a Pareto improvement (a change that makes at least one person better off without making anyone else worse off), and they freely admitted that their reform would not help everyone. "School Boy," for example, stated, "I will admit that there are a few men that it [the stock law] will not suit-though I think it will benefit twenty-five where it will injure one." In similar fashion, J. O. R. Word reasoned, "Admitting the no fence law would work a hardship against a few, would it not be the part of wisdom to legislate for the best good of many[?]" "Submuloc" of Jackson County agreed: "We need not hope to please everybody, for that is impossible. Our object should be to promote the general good, and our motto 'Pro Bono Publico.' "86 In a system of majority rule, the proposed law did not need to benefit everyone to be adopted.

Some historians have asserted that the fence debate split the society into two neat groups. Flynn arrayed laborers and tenants of both races along with "very small farmers, the poorer end of the landowning class" on one side and richer white landowners on the other ${ }^{87} \mathrm{Hahn}$ saw the combatants as "the mass of Upcountry yeomen, tenants, and laborers" against "landlords, merchants, and business interests." ${ }^{88}$ This is not, however, the only possible division. If voters cast their ballots for the stock or fence law so as to maximize their expected incomes, if the market for labor was competitive, and if transaction costs were so high that private agreements were not a viable solution, then the lineup of socioeconomic groups ought to have been more complex than Flynn and Hahn claim. ${ }^{89}$

${ }^{86}$ Carrollton Carroll County Times, September 1, 1882; Carrollton Carroll Free Press, May 1, 1885; and Jefferson Jackson Herald, March 20, 1885.

${ }^{87}$ Flynn, White Land, Black Labor, 145.

${ }^{88}$ Hahn, Roots of Southern Populism, 248 and 262 (quotations).

${ }^{89}$ The competitiveness of the postbellum southern labor market and the markedly free geographic mobility of black laborers are discussed in Robert Higgs, Competition and Coercion: Blacks in the American Economy, 1865-1914 (Cambridge, London, and Melbourne, 1977), 37-55; Stephen J. DeCanio, Agriculture in the Postbellum South: The Economics of Production and Supply (Cambridge, Mass., and London, 1974), 16-76; Joseph D. Reid, Jr., "Sharecropping as an Understandable Market Response: The Post-Bellum South," Journal of Economic History, XXXIII (March 1973), 106-30; Gavin Wright, Old South, New South: Revolutions in the Southern Economy Since the Civil War (New York, 1986), 64-70; and William Cohen, At Freedom's Edge: Black Mobility and the Southern White Quest for Racial 


\title{
TABLE 1
}

\author{
OCCuPATIONS OF Household Heads \\ Carroll and Jackson Counties, Georgia, 1880
}

\begin{tabular}{|c|c|c|c|c|}
\hline \multirow[b]{2}{*}{ Occupation } & & \\
\hline & Carroll & Jackson & Carroll & Jackson \\
\hline \multicolumn{5}{|l|}{ Farmer } \\
\hline Landholding ${ }^{a}$ & 45.3 & 43.6 & 5.4 & 5.1 \\
\hline Non-Landholding & 25.3 & 10.0 & 37.0 & 4.0 \\
\hline Laborer ${ }^{a}$ & 13.6 & 34.9 & 41.1 & 86.2 \\
\hline \multicolumn{5}{|l|}{ Capitalists } \\
\hline Trade $^{b}$ & 2.9 & 2.3 & 0.0 & 0.1 \\
\hline Professional ${ }^{c}$ & 3.1 & 3.1 & 0.8 & 0.5 \\
\hline Service $^{d}$ & 0.2 & 0.1 & 0.3 & 0.0 \\
\hline \multicolumn{5}{|l|}{ Skilled and } \\
\hline Semiskillede & 4.5 & 3.8 & 1.8 & 1.2 \\
\hline Other Laborer & 5.0 & 2.0 & 13.6 & 2.9 \\
\hline Other & 0.0 & 0.3 & 0.0 & 0.0 \\
\hline $\mathbf{N}^{\prime}$ & 2,683 & 2,086 & 389 & 896 \\
\hline Agricultural N & 2,264 & 1,845 & 325 & 854 \\
\hline \multicolumn{5}{|c|}{$\begin{array}{l}\text { "The numbers in the "landholding farmer" and farm "laborer" rows are substantially different } \\
\text { from those that Hahn reports. The reason is that } 253 \text { white and } 44 \text { black household heads in Carroll } \\
\text { and } 173 \text { whites and } 34 \text { blacks in Jackson reported their occupations as "farmer" but were not } \\
\text { recorded in the agricultural census. We therefore considered these individuals as farm laborers. } \\
\text { 'Includes merchants, grocers, other shopkeepers, salespeople, and hucksters. } \\
\text { 'Includes lawyers, physicians, clergy, teachers, and political officials. } \\
\text { "Includes hotel, stable, warehouse, and saloon keepers. } \\
\text { "Includes artisans and helpers likely to acquire a skill such as "works in blacksmith shop." } \\
\text { 'Does not include household heads reporting no occupation, "keeping house," or "student" and }\end{array}$} \\
\hline
\end{tabular}

\begin{tabular}{|c|c|c|c|c|}
\hline & \% White Hou & ld Heads & \% Black H & old Heads \\
\hline Occupation & Carroll & Jackson & Carroll & ckson \\
\hline Farmer & & & & \\
\hline Landholding $^{a}$ & 45.3 & 43.6 & 5.4 & 5.1 \\
\hline Non-Landholding & 25.3 & 10.0 & 37.0 & 4.0 \\
\hline Laborer ${ }^{a}$ & 13.6 & 34.9 & 41.1 & 86.2 \\
\hline Capitalists & & & & \\
\hline Trade $^{b}$ & 2.9 & 2.3 & 0.0 & 0.1 \\
\hline Professional ${ }^{c}$ & 3.1 & 3.1 & 0.8 & 0.5 \\
\hline Service $^{d}$ & 0.2 & 0.1 & 0.3 & 0.0 \\
\hline Skilled and & & & & \\
\hline Semiskillede & 4.5 & 3.8 & 1.8 & 1.2 \\
\hline Other Laborer & 5.0 & 2.0 & 13.6 & 2.9 \\
\hline Other & 0.0 & 0.3 & 0.0 & 0.0 \\
\hline $\mathbf{N}^{\prime}$ & 2,683 & 2,086 & 389 & 896 \\
\hline Agricultural N & 2,264 & 1,845 & 325 & 854 \\
\hline
\end{tabular}

Source: Manuscript Population Schedules of Carroll and Jackson Counties, Georgia. The data set includes all households that the census enumerated.

First, consider landowners. If the stock law passed and a landowner expected to be a net loser, he or she would experience the full effect of the loss, all other things being equal. Clearly, as Flynn and Hahn argue,

Control, 1861-1915 (Baton Rouge and London, 1991), xi-xvi. Since there were clearly many buyers and sellers of labor in the market, since (as the population increase figures cited earlier show) labor was very mobile, and since the 1880 s were relatively prosperous years for southern farmers, those who doubt that the labor market in the upcountry was competitive bear a heavy burden of proof. Contemporaries recognized this. As a stock-law supporter in Coweta County, who was trying to convince tenants and farm laborers to support his side, put it in 1881: "Never was [there] such demand for work of all kinds as in these days." Newnan Herald, June 30, 1881. Moreover, stock-law supporters conceded, as Carroll County's "School Boy" affirmed: "We all know that th[i]s black population vote for fence and they are so prejudiced that whenever the [stock] law is carried over their heads, they will at once leave without waiting to see whether its [sic] a good or bad law." Carrollton Carroll County Times, September 1, 1882. 
yeomen farmers who relied on the open range to feed their animals should have been solidly against any redefinition of property rights. ${ }^{90}$ Wealthy stock raisers, whom they do not mention, should also have opposed any change. ${ }^{91}$ Conversely, owners of land suitable for pasture but not as appropriate for growing crops should have expected to profit from the stock law and, consequently, should have been well disposed toward reform.

If landowners could be expected to divide over the issue and tenants and laborers to support the fence law overwhelmingly, as Hahn and Flynn contend, then stock-law supporters should have had no chance of success in these two counties. Table 1 shows the occupations of black and white household heads in Carroll and Jackson Counties. Tenants and laborers of both races made up substantial proportions of the voting populations in both counties, respectively 43.9 and 46.9 of the white and 91.7 and 93.1 of the black household heads. In addition, 72.4 percent and 57.6 percent of the white farm owners in Carroll and Jackson Counties, respectively, operated farms with less than fifty acres of tilled land. In sum, yeomen, tenants, and laborers were the overwhelming majority of the electorate in both counties, and if they acted as these historians say they did, there should have been no contest over the fence law.

But tenants cannot so easily be placed in the fence-law camp on the basis of first principles as Hahn and Flynn assert. ${ }^{92}$ Imagine a landowner and a

${ }^{90}$ Explicit calculations of the amount of money that each landowner and tenant in the two counties could have expected to gain or lose from the stock law in 1880 show that 52 percent of the "winning" landowners tilled fewer than forty acres and 40 percent of the "losing" landowners tilled more than forty acres. By this measure of material self-interest, not every small farmer should have opposed the stock law and not every large farmer should have favored it. See below for a fuller explanation of the "savings" measure.

${ }^{91}$ According to a Mr. Carmichael, "We have been eaten up by big cotton planters' stock and their tenants, and the widows and orphans of our county and our immediate neighborhood have had to abandon their little farms since the war, on account of these big men and their big herds of stock." Proceedings of the Georgia State Agricultural Society, 1876 to 1878, pp. 414-15. Ellickson found in Shasta County, California, that the impetus for a move to close the range came from the depredations of the animals belonging to a large cattle raiser and that, while many small property holders favored a stock law, the major cattle owners favored continuation of the open range. "Of Coase and Cattle," 647-53.

${ }_{92}$ We use the term "tenant" generically. For our purposes it is not important to distinguish among cash renters, share tenants, or sharecroppers, because all three might or might not own animals and all might be able to bargain for pasture rights. By "tenant" we mean to imply that the farmer did not own his or her land and therefore signed a contract with a landowner specifying, for example, the rent (in-kind or cash), the level of landowner supervision, and the amount of forest and pasture provided by the owner, among other things. See Lee J. Alston and Robert Higgs, "Contractual Mix in Southern Agriculture Since the Civil War: Facts, Hypotheses, and Tests," Journal of Economic History, XLII (June 1982), 327-53; Robert Higgs, "Race, Tenure, and Resource Allocation in Southern Agriculture, 1910," Journal of Economic History, XXXIII (March 1973), 149-69; Higgs, "Patterns of Farm Rental in the Georgia Cotton Belt, 1880-1900," Journal of Economic History, XXXIV (June 1974), 468-82; Reid, "Sharecropping as an Understandable Market Responsen; and Gavin Wright, The Political Economy of the Cotton South: Households, Markets, and Wealth in the Nineteenth Century (New York, 1978), 160-80 for discussions of the contractual choices available to both the landowner and land-poor. 
tenant signing a contract stipulating that the landowner would furnish no pasture and therefore the tenant had to provide for his or her animals elsewhere. In the rental contract between James Willbanks and C. M. Wood, a landlord from Harmony Grove, Jackson County, for example, the subject of pasturage was made quite explicit. Not only was Willbanks "to take care of said farm as it was his own," but it was stated also that "there is to be noe pastureing on the land of said place that are in cultivation." rental contract forbade pasturing on cultivated acreage and provided no pasture or unimproved land on which animals could forage, tenants then had four options: they could pen their animals and feed them purchased grain or fodder grown on their own small farms, send animals out into the forest to find food, rent pasture, or keep no animals. ${ }^{94}$ Whether a tenant signed such an agreement or received pasture as part of the contract, the net income that each of these tenants expected to receive should have been roughly equal, holding everything else constant, if the market for labor was competitive across the region. Simple economic reasoning shows that under a fence-law regime, any landlord in a competitive labor market would have to offer a tenant a contract of the same total value, substituting other incentives for pasture, if he or she did not offer pasture. Otherwise, the landlord would attract fewer tenants or less competent ones. ${ }^{95}$ Similar reasoning suggests that if the stock law were adopted, competition for tenants should have compelled the landowner to compensate any tenant whose animals had previously been dependent on the open range by giving him or her pasture, taking a smaller share of the crop, or reducing the cash rent. As a group, therefore, tenants should have been indifferent between the stock and fence laws. A similar argument can be made with respect to the before and after wages of farm laborers. ${ }^{96}$

\footnotetext{
93 "Day Book of C. M. Wood," in the A. D. O'Rear Collection (Georgia Department of Archives and History, Atlanta).

${ }^{94}$ In Carroll County 714 of 910 tenant farmers (78 percent) reported no pasture or unimproved land, and in Jackson County 144 of 344 tenants (42 percent) were in the same situation, according to our 100 percent sample of the 1880 Agricultural Manuscript Schedules of the U.S. Census. This census, of course, predated the adoption of the stock law anywhere in either county.

${ }^{95}$ In the 1880 census, 5 percent of the tenants and 18 percent of the farm owners in Carroll County reported having pasture. In Jackson County, the proportions were 15 percent and 34 percent, respectively. Ninety-seven to 98 percent of the landowners in the two counties reported having pasture, forest, or unimproved land on their places, compared to 22 percent of the Carroll County tenants and 60 percent of those in Jackson County. Nearly every landowner in both counties reported owning at least one non-draft animal, as did 89 percent of the tenants in Jackson County and 96 percent in Carroll County. Three conclusions may be drawn. First, especially in Carroll County, large numbers of tenants must have loosed their animals on the land of their landlords or on that of neighbors; for these people, the imposition of the stock law posed at least shortterm difficulties. Second, nearly all landowners had some available unimproved land where if water was available, stock could be pastured. Third, even before the stock law, some farmers-a third of the owners in Jackson County-did fence in their animals, despite the lack of a law requiring it; for them, the stock law was a pure benefit.

${ }^{96}$ Since holdings of animals were listed only in the agricultural schedule of the U.S.
} 
Contemporaries understood the logic of market competition well. Jackson County's "Progress" asserted that the stock law would make both landowners and their tenants better off. "The income of tenants and wages of hirelings will be regulated by the profits of the land owners .... Renters now demand houses for their families, and why not demand, under the new law, pasturage for their stock with the same propriety? This they will do, and receive it at far less cost to the owner than is required to repair fences." Similarly, the Jefferson Jackson Herald editorialized: "It is pure fallacy to say that the laborer or tenant, or, as the demagogues have it, the poor man, will suffer by it. The man who will have the burden to bear will be the man who owns the land. He will be compelled to furnish pasturage for his tenants or not get them, and it is impossible for him to do without help." "Tenant" believed that "whoever furnishes the best pastures will certainly get the best tenants, as it is all bosh about the land-holder being more independent than the tenant, for what is his land worth to him without labor?" In Rockdale County, which was one of the first to pass the stock law, the editor of the county newspaper observed that "landlords see who can arrange the best pastures to secure the best tenants." 97

This analysis is supported, rather than undermined, by the constant assertions from the fence-law side that the stock law would damage tenants. The reason that they showed unusual concern for the poor, even for the black poor, while they made less direct appeals to cattle raisers and farmers who lived in sparsely settled areas, we suggest, is that the interests of the latter two groups were much more obvious than those of tenants. Tenants received so much attention in the debate because they were the swing voters. The same logic, moreover, suggests that there was no widespread coercion of tenants by landlords to vote one way or another in these secret ballot elections: if tenants' votes could be easily won through pressure,

census and since only landowners and tenants were listed in that schedule, it is impossible to determine exactly what percentage of wage laborers owned animals. If a laborer did own a cow or pig and if he kept the animal on the open range, he would experience a decrease in real income when the stock law was imposed because he would have had either to rent pasture and purchase feed or to sell the animal. Alternatively, a laborer who owned no animals was probably indifferent between the two laws, at least in the short run. If he expected to own stock eventually, then he might have favored the open range. (Since the average age of both white and black household heads who were wage laborers was less than that of cash renters and owners in both Carroll and Jackson Counties in 1880, laborers may have expected to move up the agricultural ladder as they aged.) However, since improved acreage would have increased and fences for pastures needed to be built if the stock law were enacted, the short-term demand for wage labor might have increased in that case, causing upward pressure on wages. Overall, in the long run, the competitive market for labor should have equalized the wage of laborers in stock-law areas with that of those in nearby open-range lands, less moving costs.

${ }^{97}$ Jefferson Jackson Herald, June 24, 1881 ("Progress" quotation), June 10, 1881 (second quotation), September 25, 1885 ("Tenant" quotation); and unidentified Rockdale County newspaper, quoted ibid., August 24, 1883. Similarly, see A. R. Burch, in Newnan Herald, June 30, 1881; J. B. McDaniel of Henry County, in Carrollton Carroll County Times, August 4, 1882; and Jefferson Jackson Herald, October 31, 1884, and August 31, 1885. 
why bother appealing to their intellects?

Some renters, such as future Populist I. H. P. Beck, announced, "I am going to vote for 'no fence' because I think it will be to my interest to do so and every other renter," while other debaters disagreed. ${ }^{98}$ Thus, an anonymous writer in Carroll County declared that the stock law

is ultimately going to be the ruin of the people and most especially the poor people that have no where to keep their stock. They are entirely dependent upon the land owners for pasture for which he will charge them more than double what their milk and cow is worth. ... There is not one man out of ten that will let them have pasture room free of rent. . . It is time now for the poor people to open their eyes and to come forward and stand up for their rights and not allow themselves to be led by the cunning land owners any longer and to come out and say that we want a fence and turn out en masse and carry the election for a fence ....99

Landowner "L. F. L." asked, "How many of us Carroll people have lands to spare for pasture. How many of you colored and renters are able to pay Mr. A. or C. two or three dollars a month to keep your cow in his pasture, and pay your rent." 100 Lindsay J. Jones of Snake's Creek, who as'a member of the Democratic county executive committee in 1892 fought against the Populists, put the rhetoric most picturesquely: "I want to say to the voters of Carroll county, that we as poor men, and negroes, do not need the [stock] law, but we need a democratic government and independence, that will do the common people good. If the rich men wants to put their stock up in pens all right." 101 Or, as one tenant farmer bluntly observed, "This [stock] law will simply take rights away from the poor man and give them to the rich." 102

The material conditions of some fence-law supporters lent a discordant note to their apparently radical appeals to lower-class interests. John Stogner owned a farm worth two thousand dollars, nearly four times that of the average farm in Carroll County in 1880. Although he reported no permanent pasture to census officials, Stogner did possess thirteen cows and cattle, fifteen swine, and forty sheep, and he planted ten acres of cotton and twenty-five of corn. During the 1880 s, he had a sufficiently large herd that he drove them to Atlanta to market. ${ }^{103}$ But to listen to his rhetoric, he was a

98 Carrollton Carroll Free Press, May 15, 1885. For a similar statement, see H. N. Timmons, ibid., June 19, 1885.

${ }^{99}$ Ibid., June 19, 1885.

100 Ibid., April 24, 1885. Most reports of similar arguments come from stock-law proponents who state them and then attempt to refute them. See, e.g., Jefferson Forest News, May 14, 1880; Jefferson Jackson Herald, June 10, 1881, August 24, 1883, August 2, 31, 1885, and February 26 and March 5, 1886; Carrollton Carroll Free Press, May 1, 1885; and Charlotte (N.C.) Democrat, quoted in Southern Cultivator, XXXIV (May 1876), 178-79.

${ }^{101}$ Carrollton Carroll Free Press, May 15, 1885. For Jones's membership on the county executive committee, see ibid., April 8, 1892.

${ }^{102}$ Quoted in Flynn, White Land, Black Labor, 131.

${ }^{103}$ Carrollton Carroll Free Press, May 20, 1887. 
representative of another class. He condemned the stock law as "the greatest curse upon the poor laborer that has been since the civil war. We were told in 1859 that secession was the greatest thing that the South could do, so it was to lead her into destruction. It was a rich mans war and a poor mans fight, so will the stock law be a benefit to a few landlords who have plenty of water on their lands while nine tenths of the people will be in a deplorable condition." If the stock law passed, according to Stogner, "the common laborer will be the ones that will be the sufferers ... and why should we try [to] oppress this class any worse. God makes the grass[,] the mountaines crown, and corn in valleys grow, so lets not try to deprive our poor neighbors from receiving his blessing...." Abner Nixon, whose farm was worth one thousand dollars and who valued his livestock at the not inconsiderable sum of two hundred dollars, added a historical note to predictions of the law's effect: "The stock law will divide the people of this county into classes similar to the patricians and plebians of ancient Rome, which unhappy division, was the source of much contention, injustice, violence and blood shed, and finally the overthrow of the republic, the kingdom and the empire, and brought on the dark ages of the world."104

Some stock-law supporters lent credence to the class oppression charges of their critics. Although he himself held no land, "L." contended that "the non land holding class have no right to vote on this subject." ${ }^{105}$ Favoring a property qualification for every election and accusing a fence-law proponent of being pro-black, " $L$." thought it "sensible ... to allow the landholders to say, whether they shall fence their lands or not. ... Well do I know, to my sorrow, that the negroes and one fourth of the whites have been allowed the privilege of going to the ballot box! That is what is the matter with the country today!" 106 One bizarre proposal even aimed to disfranchise landowners who had not erected fences around their land. ${ }^{107}$

While disavowing support for black suffrage, fence-law proponents condemned these disfranchisement proposals. Philo H. Chandler, a Democratic party leader from the Kansas district of Carroll County during the 1880 s and 1890 s who later became a stock-law supporter, denounced "such a law to prohibit any one from voting [as] wickedness in the eye of the law, and the eye of God." Moves to disfranchise all blacks or propertyless whites, he wrote, "are tyrannical and we are opposed to them from the fact that we live in an independent government by the people." 108 "Mill Boy"

${ }^{104}$ Ibid., June 26, 1885.

${ }^{105}$ Carrollton Carroll County Times, May 3, 1878.

${ }^{106}$ Ibid., June 7, 1878. For similar comments, see Thomas P. Janes, Annual Report of Commissioner of Agriculture of the State of Georgia for the Year 1875 (Atlanta, 1876), 66; and Proceedings of the Georgia State Agricultural Society, 1876 to 1878, pp. 419-22. In 1891 the Georgia state legislature considered and overwhelmingly rejected a bill to disfranchise non-landowners in stock-law elections. See Carrollton Carroll Free Press, August 7, 1891.

${ }^{107}$ Carrollton Carroll County Times, May 3 and June 7, 1878; and Jefferson Jackson Herald, April 3, 1885.

${ }^{108}$ Carrollton Carroll County Times, May 17 (first quotation) and June 21 (second 
responded to the proposition of " $L$." by asserting that "if he can scratch out that clause in the constitution that entitles them [blacks] to vote, I dont suppose that there are many Mill Boys that would cry about it. But sir, for God's sake dont disfranchise a white man, just because he is poor."109

Proponents of the stock law, disturbed by the actual or potential appeal of their critics' argument that tenants would be hurt by abandoning free grazing, convinced the state legislature to amend state law. After 1881, in subcounty militia districts where the stock law was voted into effect, but not in whole counties, landlords were legally required to furnish tenants with sufficient pasture to accommodate one cow and one calf, provided that the tenant shared the work of fencing. ${ }^{110}$ Contemporary debaters were well aware of this legal guarantee. When "Ripples" cited it before a countywide election, "Con" wrote in the next week, pointing out that it applied only to arrangements adopted in district referenda. ${ }^{111}$

Thus, each side fought for the tenants' support in the usual ways of political campaigners, raising fears on the one hand and seeking to allay them on the other. Had tenants' interests been more obvious, there would not have been such a loud debate, and they would have voted more overwhelmingly for the fence law than they in fact did, as we show below.

Landowners, tenants, and laborers were not the only socioeconomic categories that were relevant to the fence-law controversy. Twenty-one percent of the household heads in the two counties in 1880 were African Americans. In the context of southern political campaigns in the 1880 s, the fence-law controversy generated relatively little race-baiting. Since nearly everyone expected blacks to vote overwhelmingly against the stock law, it is surprising that there were as few charges as there were that fence-law supporters wished "to array ignorant negroes against intelligent white people." 112 Instead, those who favored the stock law often asserted that blacks, as well as many whites, did not properly understand their own interests. "The negroes," said S. B. Orr, for example, "oppose it through prejudice and ignorance." 113 Whatever traditional yeoman community there was in the upcountry, blacks did not fit into it comfortably, and both sides

quotation), 1878. Chandler converted to the stock-law side by 1882 . For this switch and his later Democratic party leadership, see ibid., July 7 and August 18, 1882, and June 6, 1884; and Carrollton Carroll Free Press, July 8, 1892.

${ }^{109}$ Carrollton Carroll County Times, May 17 and June 21 (quotation), 1878.

${ }^{110} \mathrm{Ga}$. Acts ... 1880-81, No. 401, pp. 79-81. This provision increased the proportion of tenants who could be expected to benefit from the imposition of the stock law from 47 to 80 in Carroll County, and from 30 to 71 in Jackson County. For details of these calculations, see Kantor, "Razorbacks," 877-78.

${ }^{111}$ Carrollton Carroll County Times, September 1 and 8, 1882.

${ }_{112}$ See, e.g., Jefferson Jackson Herald, June 10 and 24, 1881, and October 31, 1884; Carrollton Carroll County Times, September 1, 1882; and Carrollton Carroll Free Press, May 1,1885 (quotation).

${ }^{118}$ Carrollton Carroll Free Press, May 22, 1885. Similarly, see Newnan Herald, July 7,1881 . 
appealed to them largely in their economic roles as tenants and wage laborers, rather than as African Americans per se. ${ }^{114}$ It was another sign of the economic, rather than cultural, nature of the homespun debate.

Hahn treats the residents of small towns as merely commercial interests, neglecting the fact that their gardens and noses had much to gain from controls on stray pigs and cows. ${ }^{115}$ While to a twentieth-century suburbanite the issue may be merely symbolic, to a nineteenth-century villager it may well have been primarily olfactory. Although they made up only 13 percent of the household heads in 1880 , before the completion of the major railroads that served the two counties, townspeople provided a core of support for the stock law. ${ }^{116}$ In 1886 Carrollton imposed the stock law by town ordinance. ${ }^{117}$ In the 1881 election in Jackson County, the two most "urban" of the county's eleven precincts provided 48 percent of the countywide vote in favor of the stock law. ${ }^{118}$

To test the Flynn/Hahn two-class model against more complex alternatives, we focus on the five countywide referenda on the stock law held in Carroll County from 1881 to 1890 - in January 1882, September 1882, July 1885 , July 1887 , and July 1890 - and the two held in Jackson County in July 1881 and September $1883 .{ }^{119}$ In addition, we use information from local option elections in many of the militia districts, which were sporadically and incompletely reported in the newspapers. We pay particular attention to changes in the voting patterns over time.

Although the fence side consistently attracted a majority of those casting ballots in both counties, there are two important trends in the data, only the first of which has been stressed by previous historians (see Table 2). The fence law gradually lost support throughout the 1880 s. As the time-series of turnout figures demonstrates, however, this decline was overshadowed by the dramatic decrease in participation on both sides of the issue. ${ }^{120}$ The more numerous elections in Carroll County most clearly show the rise and fall of the fence debate's fury. An increase in voter turnout by almost 17 percentage points between January and September 1882 is certainly an

${ }^{114}$ Jefferson Jackson Herald, June 10, 1881, and August 24, 1883; and Carrollton Carroll Free Press, April 24 and May 15, 1885.

${ }^{115}$ Hahn, Roots of Southern Populism, 256-57.

${ }^{116}$ Thirteen percent of household heads told census takers that they resided within town limits. The proportion of people living in civil divisions that contained towns was much larger. In 1890, for instance, 43.2 percent of Carroll County's population lived in the civil divisions that contained Carrollton, Villa Rica, and Temple. The proportion of townspeople by this measure in Jackson County was only about half as large as that in Carroll.

${ }^{117}$ Carrollton Carroll Free Press, March 26, 1886.

${ }^{118}$ Jefferson Jackson Herald, July 8, 1881.

${ }^{119}$ Complete returns are reported in Kantor, "Property Rights and the Dynamics of Institutional Change: The Closing of the Georgia Open Range, 1870-1900" (Ph.D. diss., California Institute of Technology, 1991), 92-94.

${ }^{120} \mathrm{Hahn}$, Roots of Southern Populism, 266-67, notes the decline in participation but does not emphasize that it was nearly equal on both sides of the fence. 


\section{TABLE 2}

Trends in Voting and Turnout in Stock-Law ReFerenda in CARRoll and Jackson Counties, Georgia, 1881-1890

$\begin{array}{cr}\% \text { of Votes } & \text { Turnout in \% } \\ \text { for Stock Law } & \text { of Adult Males }\end{array}$

\section{Carroll County}

January 1882

September 1882

July $\quad 1885$

July $\quad 1887$

July $\quad 1890$

27.7

28.9

33.3

35.7

38.6
62.3

79.2

59.9

50.2

19.1

\section{Jackson County}

July $\quad 1881$

September 1883

SourCes: Carrollton (Ga.) Carroll County Times, January 13 and September 15, 1882; Carrollton (Ga.) Carroll Free Press, July 3, 1885, July 8, 1887, and July 4, 1890; and Jefferson (Ga.) Jackson Herald, July 8, 1881, and September 14, 1883.

indication of the intense competition between the fence- and stock-law factions. As the editor of the Carrollton Carroll County Times remarked after the second ballot in his county: "No election for a long time in Carroll has excited more interest than the election last Saturday on the fence question. Exciting the interest it did, of course there was a full vote polledlarger, we believe, than any we have had in a long time." ${ }^{121}$ By 1885 the intensity on both sides began to wane-almost twenty percentage points fewer eligible voters cast ballots-and the stock law gained marginally at the polls as a result of the diminished interest. By 1890 turnout in the stocklaw referendum fell to only 19 percent. If Populism was, among other things, an outgrowth of the fence-law struggle, it seems counterintuitive that the temperature of the controversy cooled as the 1890 s approached.

While proponents of the stock law were able to increase their relative share of the electorate over time, their base of support in Carroll County was quite unstable. Table 3 displays the transition matrices between the first and second elections in Carroll and Jackson Counties, and between the second and third elections in Carroll. ${ }^{122}$ The transition matrices contain

121 Carrollton Carroll County Times, September 15, 1882.

122 Since the number of districts in Carroll County was small and since the relationships between the pre-and post-1885 elections were very nonlinear, violating the assumptions necessary to estimate transition matrices, we confine our analysis here to the elections through 1885. 


\section{TABLE 3}

Transition Matrices

JACKson AND Carroll Counties, Georgia

Panel A: Carroll County, January-September 1882 Elections

\begin{tabular}{llrccc} 
& & \multicolumn{4}{c}{ SEPTEMBER } \\
& & \% Fence & \% Stock & \% Abstain & Mean \\
J J Fence & 0.920 & 0.052 & 0.028 & 0.496 \\
& \% Stock & 0.036 & 0.671 & 0.293 & 0.135 \\
& \% Abstain & 0.286 & 0.196 & 0.518 & 0.369 \\
& Mean & 0.603 & 0.197 & 0.200 &
\end{tabular}

Panel B: Carroll County, September 1882-July 1885 Elections

\begin{tabular}{llrccc} 
& & \multicolumn{4}{c}{ JuLY 1885} \\
& & \% Fence & \% Stock & \% Abstain & Mean \\
SEPTEMBER & \% Stonce & 0.764 & 0.034 & 0.202 & 0.603 \\
1882 & \% Abstain & 0.015 & 0.500 & 0.485 & 0.197 \\
& Mean & 0.178 & 0.590 & 0.233 & 0.200 \\
& & 0.430 & 0.181 & 0.390 &
\end{tabular}

Panel C: Jackson County, 1881 to 1883 Elections

\begin{tabular}{llrccc} 
& & \multicolumn{4}{c}{1883} \\
& & \% Fence & \% Stock & \% Abstain & Mean \\
1881 & \% Fence & 0.660 & 0.023 & 0.317 & 0.400 \\
& \% Stock & 0.002 & 0.994 & 0.004 & 0.139 \\
& \% Abstain & 0.283 & 0.107 & 0.610 & 0.461 \\
& Mean & 0.383 & 0.181 & 0.436 &
\end{tabular}

estimates of the probability that voters who supported one side in one election continued supporting that position, switched to the other side, or abstained from voting in a subsequent contest. ${ }^{123}$ While an estimated 92 percent of the fence-law voters in Carroll's first election in January 1882 voted for the status quo again in September of that year, only 67 percent of the stock-law voters continued their support in September. Moreover, of those who voted for the stock law in January, 29 percent simply did not vote the second time. This is surprising, since the interval between the two elections was so short and since overall turnout rose by 17 percentage points from the first to the second contest. It is interesting to note that

\footnotetext{
${ }^{123}$ Because some estimates calculated by ordinary least squares fell outside the logical 0 100 percent bounds, we have estimated the equations underlying these tables in logit form. For a discussion of the use of the logit transformation in ecological regression, see J. Morgan Kousser, "Making Separate Equal: Integration of Black and White School Funds in Kentucky," Journal of Interdisciplinary History, X (Winter 1980), 399-428. For details of the estimation procedures in this paper, see Kantor, "Property Rights," 86-88 $n 61$.
} 
almost 29 percent of the nonvoters in the first election supported the fence law in the second election, while about 20 percent of the newly mobilized cast their franchises for the stock-law position.

Panel B of Table 3, which contains estimates of behavioral continuity and change in Carroll County from the September 1882 election to the one in July 1885 , shows an even greater pattern of volatility, especially on the stock-law side. Of those who voted for the new institution in September 1882 , only half remained faithful through the next election, and almost half abstained. Stock-law proponents attracted 59 percent of those who had not voted in 1882; otherwise, the stock law's showing in 1885 would certainly have been even more meager. Conversely, the fence-law faction was able to maintain approximately three-fourths of its support over this period, with most of the remainder abstaining in the later election. In sum, Carroll County's stock-law coalition did not vote with the vigor that we would expect from a self-conscious class of "merchants, big landlords, and other commercial interests" out to impose a new economic order with themselves in social and economic control. Moreover, the interests of fence-law supporters were apparently either so obvious that they did not need an organization to succeed or, contrary to Hahn's claim, they were able to "develop an organizational apparatus to mobilize their ranks and inspire confidence in their numerical strength." 124

Panel C of Table 3 shows that Jackson County's stock-law coalition was extremely cohesive between 1881 and 1883 . The fence-law side retained two-thirds of its backers over the same period and gained about 28 percent of those who had abstained at first. Although the stock-law group was able to hold its support in Jackson County through 1883, the law's proponents were continuously overpowered by the numerical strength of the fence-law advocates. Carroll County's stock-law voters, by contrast, were too fickle and too few to prevail at the county level. ${ }^{125}$

Frustrated by their repeated countywide defeats, stock-law supporters began to concentrate their attention on adopting the law at the militiadistrict level. By the 1887 countywide election in Carroll, eight of the fifteen districts had adopted the stock law in district referenda. In four of these eight districts, however, the fence law had originally been declared the victor, but after being contested on the ground of ballot fraud, the Carroll County Ordinary (judge) overturned the results and declared the

\footnotetext{
${ }^{124} \mathrm{Hahn}$, Roots of Southern Populism, 256 (first quotation) and 267 (second quotation). Note that Carroll County stock-law supporters did not shift or drop out before 1883 as a result of district election victories, because, as far as we know from the newspapers, there were no district-only stock-law referenda in the county before 1884 .

125 "F-tests" for the "null" hypothesis that there was no statistical relationship between voting in each pair of elections yield values of $12.9,6.0$, and 15.0 for panels $A, B$, and $C$, respectively, which means that the null hypothesis can be rejected at the .01 level in every instance. "R-squares" for the logit equations in each panel are 0.691 for panel A, 0.512 for panel B, and 0.779 for panel C. All are reasonably good fits.
} 
districts stock-law areas. ${ }^{126}$ The precise wording of the law, no doubt, confused the voters: the county election ballots were required to read either "fence" or "no fence," the latter meaning the stock law. The district election ballots, however, had to be either "for fence" or for the "stock law." The election in Carroll's Bowdon district was particularly muddled: the precinct managers certified the result in favor of the fence law 102 to 73; however, the actual vote cast was 73 for "stock law," 68 "for fence," 30 for "fence," 2 for "a fence," and 2 for "the fence." The Carroll County Ordinary, after hearing arguments from both sides, threw out 33 votes not cast "for fence," thus leaving a majority of 3 votes for the stock law. ${ }^{127}$ In the remaining four districts, however, the stock law won unequivocal majorities.

Thus, by taking advantage of legal changes and ambiguities and by concentrating their attention on the much smaller districts, stock-law supporters were able to close the open range of Carroll and Jackson Counties little by little. The election rules were designed by the legislature to allow stock-law supporters to prevail in the areas that mattered most to them, those closest to either their farms or town property. ${ }^{128}$ Once a district was recorded as voting for the stock law, that decision could not be reversed. As more and more districts jumped the fence, the area of open range and, therefore, its value to any stock owner in fence-law territory declined.

Since more than half of Carroll County's districts were already under the stock-law rule by July 1887, it is not surprising that only about half of the eligible voters cast ballots in that month's countywide stock-law election. Within the next three years, five more districts imposed the stock law, and turnout in the 1890 contest plummeted to 19 percent. The decrease was

${ }^{126}$ It is difficult to consider Samuel J. Brown, the Carroll County Ordinary in 1887, an agent of capitalism or one of the "agrarian bourgeoisie." In 1880 the only man named S. $\mathrm{J}$. Brown in the county lived in Carrollton but owned a twenty-acre farm worth $\$ 500$, of which he tilled thirteen acres. He apparently kept his one horse, one cow, one other head of cattle, and seven pigs in a one-acre pasture; or perhaps to prevent overgrazing on his own land, he allowed some of them to run at large. According to our measure of prospective gains and losses if the stock law were adopted, which we explain below, Brown would have gained the small sum of $\$ 40.74$ if the stock law had been adopted in 1880 . In the 1894 tax records, he is listed as owning fifty acres valued at $\$ 200$ in the Bowdon district but no town or paper assets. His total wealth was reported to be $\$ 325$. By comparison, the average wealth of the thirty-four members of the Populist county executive committee in that year was $\$ 635$, and that of the fifty-three members of the Democratic county executive committee was $\$ 1,754$. See Kantor, "Property Rights," 280 . Even allowing for a possible understatement of his resources, it does not seem that Brown was a rich man.

127 Carrollton Carroll Free Press, March 18 and 25, 1887.

${ }^{128}$ The success of planters and townspeople in convincing the legislature to change the rules on stock-law voting in 1881 contrasts dramatically with the apparent inability of the largest capitalist interest in the state, the railroads, to craft the stock-law rules in their favor. Since animals who wandered onto the tracks slowed trains and caused lawsuits, railroads, which by the 1880 s stretched throughout the state, had a considerable stake in imposing the stock law statewide. If capitalistic interests increasingly dominated the state's politics, as Hahn implies, one would expect that railroads would have had more influence in the stock-law controversy than they did. 


\section{TABLE 4}

WERE STOCK-LAW SUPPORTERS CULTURAL IMPERIALISTS?

Turnout and Support for the Fence Law in Carroll County, Georgia, REFERENDA, 1882-1890

Election Date

When District Adopted Stock Law for Itself Before $1887 \quad 1887-1890 \quad$ After 1890

Panel A: Turnout in Percentage of Eligible Voters

$\begin{array}{llll}\text { January } 1882 \text { County } & 59.9 & 64.3 & 73.9 \\ \text { September } 1882 \text { County } & 75.0 & 87.1 & 88.7 \\ \text { 1885 County } & 57.4 & 63.8 & 69.0 \\ \text { District } & 61.5 & -65.2 & 71.2 \\ \text { 1887 County } & 41.6 & 61.3 & \\ \text { District } & - & 23.8 & 55.8 \\ 1890 \text { County } & 12.9 & & 72.3 \\ \text { District } & - & & \end{array}$

Panel B: Percentage in Favor of Fence Law ${ }^{\star}$

\begin{tabular}{|c|c|c|c|}
\hline January 1882 County & 37.7 & 56.4 & 67.3 \\
\hline September 1882 County & 47.9 & 70.6 & 79.0 \\
\hline 1885 County & 59.4 & 78.5 & 81.9 \\
\hline District & 47.8 & & \\
\hline 1887 County & 55.7 & 71.8 & 81.9 \\
\hline District & & 51.9 & \\
\hline 1890 County & 46.4 & 69.7 & 78.8 \\
\hline District & {[} & - & 50.9 \\
\hline
\end{tabular}

Note: "These are the original returns, some of which were thrown out by the Carroll County Ordinary. Some districts voted more than once.

most dramatic in the stock-law districts. ${ }^{129}$ Table 4 shows Carroll County's voter turnout and election results for three types of districts: those that adopted the stock law by the 1887 countywide election, those that adopted after the 1887 election but before the 1890 contest, and finally, those districts that did not adopt the law until after 1890 . The table tracks voter activity from 1882 to 1890 , including district referenda, where the returns were available. What is apparent from Panel A of Table 4 is that once districts adopted the stock law, many voters apparently felt that the costs of casting a ballot for either option were too high to justify a trip to the polls. ${ }^{130}$ 143.

${ }^{129}$ See Carrollton Carroll Free Press, July 18, 1890; and Bonner, Georgia's Last Frontier,

${ }^{130}$ See Anthony Downs, An Economic Theory of Democracy (New York, 1957), Chap. 14, for a discussion of calculations on the question of whether or not to vote. 
The first group of districts sent 75 percent of their eligible voters to the polls in September 1882. In the 1885 countywide and district referenda and in later elections after these districts adopted the stock law, turnout declined, falling to 41.6 percent in 1887 and to a low of 12.9 percent in 1890 . The second set of districts followed the same general pattern, with turnout in excess of 60 percent in January and September 1882,1885, 1887, and in their district elections but only 23.8 percent in the 1890 countywide ballot. In regions where the open range continued to be argued actively, however, voters continued to go to the polls in large numbers. Of the voters who lived in districts that retained the open range through the 1890 election, 55.8 percent went to the polls in the last countywide election, and 72.3 percent in referenda in their own districts-in striking contrast to the 12.9 and 23.8 percent turnout in the districts that had already adopted the stock law for themselves. And as Panel B of Table 4 shows, the open-range districts voted faithfully for the fence law in county referenda throughout the election process.

Tables 3 and 4 mar Hahn's image of helpless partisans of common rights overwhelmed by a juggernaut of merchants and rich farmers who represented the impersonal free market. ${ }^{131}$ Fence-law partisans won all seven countywide elections in the two counties from 1881 to 1890; and their pattern of support was, on the whole, much less volatile than that of their opponents. Even more serious for Hahn's thesis, after gaining the adoption of their preferred arrangement in their own districts, most stock-law supporters abstained in subsequent countywide referenda, rather than seeking to impose their views on open-range areas. This is not a conclusion that depends on even the very simple statistical analysis of election returns presented in Table 4, for contemporaries repeatedly commented on the issue. For instance, the pro-stock law Carrollton Carroll Free Press agreed with a correspondent who thought it "wrong for the county to pass on the question as to whether they should have the stock law in his district as the policy has been heretofore to let the districts act upon this matter for themselves." The proper policy, the editor wrote, was to "let each district work out its own salvation, but don't force it on a district whether they are willing or not." ${ }^{132}$ Another correspondent, from a district that voted in favor of imposing the stock law on itself in May 1890 but against requiring it for the whole county little more than a month later, declared, "We got it by district election and we did not believe it was right to force it on those districts who did not have a majority to get themselves." 133

On the same day in 1890 that Carroll County stock-law supporters abstained in droves, the same voters decided another issue in a local

${ }^{131}$ Hahn, Roots of Southern Populism, 262 and 267.

132 Carrollton Carroll Free Press, June 27, 1890.

${ }^{133}$ Ibid., July 18, 1890. 
referendum. Bitterly contested for years, the proposal to issue bonds to erect a new county courthouse attracted 1,432 ballots in districts that had adopted the stock law. But strikingly, only 650 of the same voters who had already assumed the cost of going to the polls in the two-issue election bothered to express their opinions on the countywide fence question. In those districts where the stock law was not yet in force, however, there were 204 ballots on the bond question and 210 on the stock law. ${ }^{134}$ This special "allegiance to local control" displayed in the 1890 election is a clear indication that fence reformers were not engaged in any sweeping plan to restructure the social or cultural basis of their economy. ${ }^{135}$ Their goal, instead, was to restructure property rights in specific local geographic areas where economic efficiencies could be captured through a redefinition of the tort liability regarding animals and fences.

If the analysis of changes in the overall vote totals partially alters the nature of the conflict as depicted by previous historians, it does not uncover the socioeconomic coalitions on each side, and it casts only a limited light on voters' motives. Did men vote for the fence law in order to voice their objections to the encroaching capitalist market and preserve a traditional community of rough equals, as Hahn contends? Did the fence-law conflict, as both Flynn and Hahn assert, divide this agricultural society into two distinct classes? Or, do the voting patterns suggest a more complex pattern of divisions, as our economic self-interest model implies?

The rich data available allows us to address these questions in more than one way. Let us first consider the order in which the militia districts in Carroll County adopted the stock law. If the self-interest thesis is correct, then those districts in which farmers should have expected to gain the most from the imposition of the stock law should have adopted it first, while those in which more farmers benefited monetarily from the fence law should have dragged their collective feet. Using our 100 percent sample of the 1880 agricultural census manuscript returns, we have constructed a measure of the extent of the savings or losses for each district in the two counties if the stock law had been put into force instantaneously in that year. ${ }^{136}$ We then calculated Spearman's Rho, a rank-order correlation

194 Ibid., July 4, 1890. As their correspondent "Martin" of Smithfield noted after the 1890 election, "We got it [the stock law] by district election and we did not believe it was right to force it on those districts who did not have a majority to get themselves. So our motto was fence and no bonds." Ibid, July 18, 1890.

${ }^{135}$ Quotation from Bonner, Georgia's Last Frontier, 143.

136 To approximate the expected savings or loss, we estimated the amount of land wasted by fence rows within each district and calculated the value of crops that could have been grown on that land, less the cost of growing them. Next, we assigned livestock to available pasturage that existed before the institutional change and estimated a feed allowance for those animals that were previously unenclosed and that would now have to be put behind fences. We subtracted the value of this feed from the net profit of the aforementioned crops. Since farmers would need to maintain fewer fences under the closed-range policy, we calculated the approximate cost of replacing broken fences 


\title{
TABLE 5
}

\author{
Definitions, Means, and Standard Deviations of Variables \\ FOR MUlTiple Regression ANAlysis
}

\section{Variable Name Dependent Variables}

Fence

Stock

Abstain

$$
\text { Variable Definition }
$$

Percent of eligible voters for fence law

Percent of eligible voters for stock law

Percent of eligible voters not voting in stock-law referendum
Mean Standard Deviation

42.4

9.0

41.6

Savings in forest Percent of farms with the stock law

Class-conflict Thesis

Tenants

Percent of household

heads sharecroppers or renters

Laborers

Land Value
Percent of household heads farm laborers

coefficient, to determine whether the order of adoption of the stock law was similar to that on our measure of savings. It was. Counting all the districts, the correlation is 0.56 , which is statistically significant at the conventional 5 percent confidence level. Excluding those districts where the County Ordi-

around crops and that around animals and added the difference between the two to the savings measure. Additionally, we assumed that farmers would bear a one-time cost of erecting new fences around their newly created pastures if the stock law were passed. As is usual in such economic indexes, our net savings measure represents the discounted net present value of these savings over an infinite time horizon. Following Roger L. Ransom and Richard Sutch, One Kind of Freedom: The Economic Consequences of Emancipation (Cambridge, Eng., and other cities, 1977), 208, we assumed an interest rate of 7 percent. For details of the calculation, see Kantor, "Property Rights," 127-28 and 295-302. 
TABLE 5 Continued

COMMUNITY AND

SOCIAL-CONTROL THESIS

Gini

Stkinfre

Town ThesIS

Town
Gini coefficient for value of owner-operated farms

Dummy variable that equals 1 if the district had adopted the stock law before the referendum, and 0 otherwise

Percent of household heads reporting town residence

\subsection{5} 0.07

Sources: For voting returns, see Table 2. Data on wealth and unadjusted number of polls were collected from the Carroll and Jackson Counties Tax Digests (Georgia Department of Archives and History, Atlanta). All of the data were collected from manuscript population and agricultural census returns.

nary overturned the initially announced results, the correlation is 0.79 , which is significant at the 1 percent level. While these results do not prove that the self-interest model is correct, they clearly lend support to it.

We also performed an ordinary least squares multiple regression analysis using county referendum returns as dependent variables and socioeconomic variables as independent variables. ${ }^{137}$ Because theoretical notions (ours among them) are often rather vague and because it is rarely obvious just how to operationalize a concept, we estimated equations with several different combinations of variables. Table 5 delineates the variables that we think give the most accurate and fair test of the various hypotheses offered by Hahn, Flynn, King, and ourselves. ${ }^{138}$ To determine the support

137 The fact, pointed out earlier, that the number of ballots in the courthouse referendum was so much larger than that in the stock-law referendum in Carroll County in 1890 justifies our decision to estimate the regression equations given in Table 5 in three separate equations, rather than by a two-stage procedure. On the fence question in Carroll County, it is obvious that men did not first decide whether or not to vote on the fence-law question, and then which way to vote. Instead, the two decisions were made simultaneously. We also estimated similar equations with logit models. Since the results paralleled those using ordinary least squares regression, we discuss the simpler models. Tests to determine whether it was appropriate to consolidate all the elections in both counties were also performed. When included in equations like those in Table 5, dummy variables that treated the counties and elections separately change the results in only one respect: in the non-pooled equations, the coefficients on the laborers variable are never significant. This does not change our overall interpretation at all. We did not add militiadistrict to countywide-referendum returns because, as we have argued at length in the text, very different considerations moved the voters in the two types of elections.

${ }^{138}$ Nearly all the different specifications of the model supported the interpretation advanced in the text. For instance, in Table 6, substituting the percentage of farms tenanted in each district for the percentage of tenants among household heads changes neither a sign of any coefficient nor the identities of the variables that are statistically significant at the conventional .05 level. Furthermore, supplanting the percentage residing in towns with the value of town real estate per capita or the percentage of forest 
for the fence- and stock-law positions among all potential voters in the seven countywide referenda in the two counties, we divided the number of votes for each side in each militia district by the estimated number of polls in each district. ${ }^{139}$

Although the definitions of most of the independent variables are selfevident, the rationale for each needs explanation. Two or perhaps three variables tap somewhat different facets of self-interest among farmers. The more unimproved forest land each district had, the more wood was available for fences, and the more room animals had to roam without intruding on crop land or garden plots. Consequently, the district's voters should have been less enthusiastic about the stock law than in more developed areas. Similarly, the higher the proportion of farmers who, according to our calculations, should have expected to save money as a result of the passage of the stock law and the lower the proportion of farmers who should have expected to lose money, the greater should have been support for the change.

A third variable, the value of white-owned farm real estate from the tax digest divided by the number of white male voters in each district, partly indexes self-interest and partly indicates class conflict. ${ }^{140}$ Those who owned either land convenient to railroad stations and markets or notably fertile land, which was most suitable for growing crops and therefore most vulnerable to the depredations of animals, had the largest material interest in overthrowing the fence law. Conversely, those who lived in districts where the farmland was less valuable, and therefore relatively more suitable for livestock and less fit for crops, had a good deal to lose from the

land with the percentage of tilled land does not change any signs or significance levels. Only sets of independent variables that are highly interrelated give appreciably different results than those in Table 6 . Because it is always difficult to interpret the parameters of strongly collinear independent variables, we employ a set of variables that captured different facets of each explanation. It is, of course, possible that we err in our operationalization of hypotheses. If so, our explicit and exact formulation of them may stimulate productive debate if others propose and test alternative empirical models. As has been widely noted, two of the chief virtues of quantitative social scientific history are the clarity that it forces and its tendency to channel debate towards questions and techniques that allow definitive answers.

${ }_{139}$ We adjusted the number of polls reported in the county tax digests upward for each district because a comparison of data from the tax rolls with the 1880 manuscript census numbers of males over 21 in each county indicated that the tax assessors, who were supposed to assess even the propertyless, missed about 45 percent of the black and 23 percent of the white male household heads in Carroll County and 30 percent of the black and 19 percent of the white male household heads in Jackson County. Since the published 1890 census does not give the number of males over 21 by minor civil division and the manuscripts for that census burned, we were forced to use the tax digest number of polls for each district for each election year, and we had to inflate every district's number of polls by the percentages for the whole county, given above.

${ }^{140}$ Because, as Table 1 above shows, only about 5 percent of black household heads in the two counties owned farms (and their farms probably had disproportionately low values), we excluded blacks from the numerator and denominator of this statistic. 
stock law, at least in the short term. Nonetheless, because this variable also scales farmers and townspeople into the relatively rich and the relatively poor, it is also an indication of class conflict and fits into part of the hypotheses of Bonner, Flynn, and Hahn. We have therefore assigned it a position in Tables 5 and 6 under the "class-conflict thesis."

Four variables express other aspects of the Hahn and/or Flynn models. Both authors hold that tenants and laborers should have feared the specter of social control that the stock law raised, as well as the material loss of free pasturage for their cows and pigs. Hahn believes that the "democratic commonwealth of producers" was strongest where wealth was most evenly distributed: "The districts lending the stock law its substantial support tended to have the closest links to market centers, the highest real-estate assessments and per capita wealth, and the greatest concentrations of land held by large landowners. It was here that merchants, big landlords, and other commercial interests wielded most influence and authority. Poorer, rural districts having more evenly distributed landholdings, on the other hand, rejected the law overwhelmingly and at times almost unanimously. Here small farmers feeling the new strains of staple agriculture had their firmest cultural foothold."141 Although Hahn offers no systematic evidence for this proposition, we tested it by calculating a Gini index of inequality of landholdings among owner-operators in each district. ${ }^{142}$ The higher the index, the more skewed the distribution and, according to Hahn, the greater should have been the support for the stock law. Finally, if the fence-law controversy was a "central feature" of an "increasingly withering attack" by elites on "common rights," as Hahn contends, then one should expect the attempt to foster social control not only to persist but, if anything, also to gain impetus after a district-level victory. ${ }^{143}$ To capture this idea, we created a "dummy" variable, that is, a variable that takes on the values of only zero and one. Calling this variable stkinfrc (for "stock law in force"), we set it at one for districts that had already adopted the stock law by the time of the relevant county referendum and at zero otherwise. If Hahn is correct, the denizens of stock-law districts should have tried to force their practices on others.

The last variable, the percentage of household heads in each district living within town limits, stands for different notions for Bonner and Hahn than it does for us. The earlier historians saw the towns as outposts of capitalism or progress and change, and as opponents of traditional practices. While we largely agree with that description, we stress that townspeople, having less forest or common land and fewer animals than

\footnotetext{
${ }^{141}$ Hahn, Roots of Southern Populism, 262 and 256.

${ }^{142}$ On the Gini index, see Satya R. Chakravarty, Ethical Social Index Numbers (Berlin and New York, 1990), 50.

${ }^{143}$ Hahn, Roots of Southern Populism, 243.
} 
rural Georgians, stood to lose little by the closing of the range and that they probably viewed other people's animals as nuisances. According to either hypothesis, town-dominated districts should have opposed the fence law. If Hahn is correct and the bourgeois were aggressively trying to expand the sphere of market relations, then they should have continued to do so even after their own districts accepted the stock law. The choice between the two interpretations of townsmen's behavior, then, lies not in the patterns of relationships of the town variable, but in those of stkinfrc.

Table 6 largely buttresses our contentions. Those voters who stood to lose money if the stock law passed voted against it, while those who stood to gain voted for it, holding other variables constant. Both coefficients of the savings variable are statistically significant. The positive and statistically significant relationship between the savings variable and nonvoting implies that prospective beneficiaries sought to maximize only their own interest, which could be done without imposing the stock-law regime on the whole county. Since the extent of unimproved land is partially taken into account in estimating expected savings, as well as in land values, it is not wholly surprising that the percentage of land listed in the census as forested has no statistically significant relationship with the votes. The coefficient for the forest variable in the fence-law equation is, however, in the predicted direction. Together, these variables alone explain 16 percent of the variance in the percentage for the fence law. If the land value variable is considered as a measure of self-interest, the three variables account for 17 percent of the variance in the vote for the fence law and 28 percent in that for the stock law. ${ }^{144}$ As Hahn observes but does not sufficiently emphasize, "simple economic interest played a large role" in fence-law conflicts. ${ }^{145}$

If the value of farm real estate per voter is considered an indication of class conflict, then it implies that those in richer areas were more likely to participate in stock-law elections, all other things being equal, and were somewhat more likely to vote for the stock law than for the fence law. The data suggests that there was a palpable division between the white land-rich and the white land-poor over the fence law.

Yet a simple two-class conflict model poorly fits the data from Carroll and Jackson Counties because group interests did not divide neatly into two parts. As our analysis of the competitive market for labor implied, tenants and laborers seem to have been largely indifferent between the fence and stock laws. In fact, the coefficients for the relationships between the percentages of tenants and laborers and voting on the issue have the opposite signs to those that the fence-law proponents' rhetoric suggested,

144 These percentages of variance explained derive from equations containing an intercept term and the variables savings and forest, in the first instance, and savings, forest, and land value in the second.

145 Hahn, Roots of Southern Populism, 268. 
TABLE 6

Multiple Regression Analysis of Seven County Referenda on Stock LaW in Carroll and Jackson Counties, Georgia

Independent Variables

Dependent Variables

Percent Fence Percent Stock Percent Not Voting

SELF-INTEREST THESIS

$\begin{array}{lclc}\text { Forest } & 0.22 & 0.00 & -0.22 \\ \text { Savings } & -0.44^{*} & 0.16^{*} & 0.29^{*} \\ \text { CLASS-CONFLCT THESIS } & & & \\ \text { Tenants } & 0.43 & 0.17 & 0.26 \\ \text { Laborers } & -0.56^{*} & 0.04 & 0.52^{*} \\ \text { Land Value } & 0.0009 & 0.030^{*} & -0.039^{*}\end{array}$

COMMUNITY AND

SOCIAL-CONTROL THESIS

Gini

0.24

$-0.33^{*}$

0.09

Stkinfrc

Town THEsIS

Town

INTERCEPT

$59.73^{*}$

7.75

$32.51^{*}$

NUMBER OF

OBSERVATIONS

92

NoTe: * - statistically significant at 0.05 level.

SOURCE: See Table 5 .

and the coefficient for the laborers was statistically significant at the conventional 5 percent level. Instead of turning out solidly for the fence law or the stock law, tenants and laborers appear to have abstained from voting. ${ }^{146}$

The regression results strongly disconfirm Hahn's cultural-conflict model. All other things being equal, the greater the equality of landholdings in a district, the stronger, not the weaker, the support for the stock law, and the coefficient is statistically significant. ${ }^{147}$ That is, controlling for other fac-

146 Because African Americans in these two counties were overwhelmingly but not entirely farm laborers, entering the percentage of blacks in each district separately into the equation leads to problems of multicollinearity. Since blacks were addressed in the debate largely in their economic, rather than racial roles, we chose to use the laborer rather than the black variable; but an equation substituting the black percentage for the farm laborer percentage produces very similar results. It is conceivable that blacks were coerced to stay away from the polls, but there was no mention of this occurring in either county. Since the Carrollton Carroll Free Press did discuss charges that Coweta County blacks had been encouraged to go to a state fair by stock-law supporters who feared that blacks would vote for the fence-law side, it seems likely that any such event, in Carroll County at least, would have been noticed in the newspaper. See Carrollton Carroll Free Press, July 16 and 23, 1886.

${ }_{147}$ If the coefficient of variation (that is, the standard deviation divided by the mean) 
tors, areas peopled by relatively undifferentiated yeomen, the sorts of places where, according to Hahn, "preindustrial republicanism" thrived, were especially likely to favor fencing in animals. ${ }^{148}$ And, as the simpler analysis of the voting already presented showed, those who lived in areas where the stock law had been put into effect through district elections did not seek to impose it on other parts of Carroll County. Instead, they largely abstained in the referenda, as did fence-law supporters in the same districts. Neither group acted as if motivated by a desire to thrust its value system on people in other areas or to protect a threatened communitarianism against hostile forces. Rather, they seem to have been responsive to their own rather narrowly drawn self-interest.

Finally, as the earlier analysis of votes also showed, and as the hypotheses of every historian who has examined the question predicted, townsmen strongly supported the stock law and opposed the fence law. Whether they did so to foist market relations on yeomen or to keep hogs and cattle from running loose in the towns is a matter of interpretation, but, as the above analysis of the stkinfrc variable suggests, the latter is the preferable interpretation.

The fence-law struggle in Carroll and Jackson Counties, the centerpiece of one of the most striking and influential recent interpretations of postbellum southern society, Steven Hahn's Roots of Southern Populism, does not represent, as he contends it does, an epic struggle between the aggressive agents of capitalism and the increasingly hapless defenders of a traditional communitarian ideology or "moral economy." The astonishingly sophisticated debate on the subject, which anticipated many of the notions of modern economists, primarily concerned practical issues-costs, profits, conservation, and demographic change. ${ }^{149}$ Those who appealed rhetorically to

for each district is substituted for the Gini coefficient, the results are almost exactly the same. The correlation between the two measures of inequality for this set of data is +0.91 .

${ }^{148} \mathrm{Hahn}$, Roots of Southern Populism, 253. It turns out that in these counties, the districts containing villages had more equitably distributed landholdings than did those in the most rural areas. This suggests that the notion of an undifferentiated yeomanry in the outlying areas should be reexamined.

149 We saw no evidence that newspaper editors, who were always anxious to feature controversy in order to build circulation, censored the fence-law side of the debate. Indeed, the editor of the Jefferson Forest News, T. S. Howard, declared (ibid., September 19,1879 ) that "we cannot tell whether this measure [the stock law] would be beneficial or not, especially at this time. And, as we are in no condition to form a correct opinion upon the subject, we refrain from giving any, but offer our columns for a fair discussion of the question, and would like to see it ventilated, for we think no harm can be done in a fair and honest discussion of the benefits or evils that will arise from this measure. We shall stand as impartial judges in the matter, and promise that both sides shall have a fair showing. We want our correspondents, to start off with, to give us the opinions of their respective communities upon the subject." In fact, the debate on both sides was remarkably full and the number of articles on the subject was quite large. In any case, local 
"traditional rights," as well as those who apostrophised "progress," often mixed these invocations with practical, calculating arguments in their letters to newspapers. The persuasive tactics of both sides reflected the late nineteenth-century upcountry society's consensus on private property and individualism. Each side devoted many words to what tenants and laborers should have expected to gain or lose from the change because in a competitive labor market, it was doubtful that this question of tort liability made much difference to the landless in the long run.

The results of both simple and more complicated statistical analyses support our interpretation of the debates and undermine Hahn's culturalconflict theory. Stock-law proponents did take advantage of the 1881 legislature's district-option law to win gradually at the militia-district level what they could not pass in countywide referenda in either Carroll or Jackson Counties. ${ }^{150}$ Having achieved their aim in subcounty districts in Carroll County, stock-law advocates made little or no effort to shackle unwilling backers of the open range in other parts of the county. Voters in districts where the objective economic benefits of the stock law were high were quite likely to adopt the new institutional arrangement sooner than those where the benefits were lower or negative. Areas where landholding was most equitably distributed, the supposed bastions of yeoman independence, actually were more likely to support the stock law than were less egalitarian districts, all other things being equal. Townspeople, as Bonner, Flynn, and Hahn all agree, favored fencing in animals, not crops, but their reasons were, we have argued, more practical than ideological. If these two counties were representative of the upland South in the late nineteenth

newspaper stories constitute the best extant source for the policy debate, and all historians who have studied the issue have been forced to rely on them.

${ }^{150}$ In Jackson County, six of the thirteen districts adopted the stock law before 1890 , but instead of holding a countywide referendum, advocates convinced the legislature to impose the stock law on the county in a special act, which was later declared unconstitutional. Georgia Acts ... 1889, No. 788, pp. 1278-79; Mathis v. Jones, 84 Ga. 804 (1890); and Camp v. Tompkins, $84 \mathrm{Ga} .812(1890)$. It was eventually reimposed through still another legislative enactment. Georgia Acts ... 1890-91, No. 12, p. 69, amended in Georgia Acts, 1892-93, No. 44, pp. 104-5. The lack of a local referendum after districts began to act in Jackson County makes it much more difficult to determine the forces behind the change there than in Carroll County. Hahn's statement in The Roots of Southern Populism, 265, that the districts that imposed the stock law on themselves in Jackson County consisted of the towns of Jefferson and Harmony Grove "along with three of the wealthier districts" is misleading. (In fact, there were four other districts that adopted the stock law in district referenda, along with Jefferson and Harmony Grove-Harrisburg, Clarkesboro, Newtown, and Hoschton.) See Jefferson Jackson Herald, October 23, 1885, and September 2 and November 11, 1887. Using total wealth per capita (the same index that Hahn uses) from the 1887 tax digest as a measure of wealth and excluding the two wealthy town districts, the other four districts that adopted the stock law in district referenda ranked $1,3,5$, and 7 , while the districts that did not adopt the stock law before 1890 ranked 2, 4, 6, and 811. The correlation is hardly overwhelming. 
century, as Hahn implicitly claims, then the fence-law controversy in the upcountry was a struggle not of cultures but of interests. ${ }^{151}$

${ }^{151}$ Hahn, Roots of Southern Populism, 9-10. 